\title{
Characterization of Simulated Low-Level Waste Grout Produced in a Pilot-Scale Test
}

R. O. Lokken

M.A. Reimus

P. F. C. Martin

S. E. Geldart

February 1988

Prepared for the U.S. Department of Energy under Contract DE-AC06-76RLO 1830

Pacific Northwest Laboratory Operated for the U.S. Department of Energy by Battelle Memorial Institute 


\title{
DISCLAIMER
}

This report was prepared as an account of work sponsored by an agency of the United States Government. Neither the United States Government nor any agency thereof, nor Battelle Memorial Institute, nor any or their employees, makes any warranty, expressed or implied, or assumes any legal liability or responsibility for the accuracy, completeness, or usefulness of any information, apparatus, product, or process disclosed, or represents that its use would not infringe privately owned rights. Reference herein to any specific commercial product, process, or service by trade name, trademark, manufacturer, or otherwise does not necessarily constitute or imply its endorsement, recommendation, or favoring by the United States Government or any agency thereof, or Battelle Memorial Institute. The views and opinions of authors expressed herein do not necessarily state or reflect those of the United States Government or any agency thereof, or Battelle Memorial Institute.

\author{
PACIFIC NORTHWEST LABORATORY \\ operated by \\ BATTELLE MEMORIAL INSTITUTE \\ for the \\ UNITED STATES DEPARTMENT OF ENERGY \\ under Contract DE-AC06-76RLO 1830
}
Printed in the United States of America
Available from
National Technical Information Service
United States Department of Commerce
5285 Port Royal Road
Springfield, Virginia 22161
NT1S Price Codes
Microfiche A01

\begin{tabular}{lr}
\multicolumn{2}{c}{ Printed Copy } \\
Pages & $\begin{array}{c}\text { Price } \\
\text { Codes }\end{array}$ \\
$001-025$ & A02 \\
$026-050$ & A03 \\
$051-075$ & A04 \\
$076-100$ & A05 \\
$101-125$ & A06 \\
$126-150$ & A07 \\
$151-175$ & A08 \\
$176-200$ & A09 \\
$201-225$ & A010 \\
$226-250$ & A011 \\
$251-275$ & A012 \\
$276-300$ & A013
\end{tabular}


Hanford Grout Technology Program

CHARACTERIZATION OF SIMULATED LOW-LEVEL WASTE GROUT PRODUCED IN A PILOT-SCALE TEST

R. 0. Lokken

M. A. Reimus

P. F. C. Martin

S. E. Geldart

February 1988

Prepared for the U.S. Department of Energy under Contract DE-AC06-76RLO 1830

Pacific Northwest Laboratory Richland, Washington 99352 


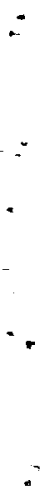
. 
A U.S. Department of Energy (DOE) program is under way at the Hanford Site near Richland, Washington, to convert the low-level fraction of selected liquid radioactive wastes to a cementitious grout form for near-surface disposal. Grout slurry, consisting of a mixture of liquid waste and a solids blend, will be pumped to near-surface disposal vaults where it will harden, thereby immobilizing the waste.

The Grout Disposal Program at Hanford is managed by Westinghouse Hanford Company (WHC) who will operate the Transportable Grout Facility (TGF). The TGF includes the Dry Materials Receiving and Handling Facility (DMRHF) and the Transportable Grout Equipment (TGE). The first waste stream to be grouted is called Phosphate/Sulfate Waste (PSW) from N Reactor Operations. Phosphate waste is primarily a dilute solution of sodium phosphate. The sulfate waste is made up of a dilute solution of sodium sulfate and a small amount of solid particulate from sandfilter backwash.

Pacific Northwest Laboratory (PNL) has been providing support to the Grout Disposal Program through pilot-scale tests, performance assessments, and formulation verification activities. A major pilot-scale test was conducted in July 1986 to assess the effectiveness of the grouting operations and to characterize grout produced with pilot-scale equipment and disposed in a monolithic form. During the test, 16,000 gallons of non-radioactive simulated PSW were mixed with a four-component blend of dry solids, resulting in 22,000 gallons of grout. The grout slurry was pumped 150 feet to a lined trench at $15 \mathrm{gpm}$.

The objectives of the pilot-scale grout test were threefold: 1) to determine the homogeneity of the grout produced under conditions similar to those planned for the TGF, 2) to evaluate performance of candidate grout processing equipment for the TGF, and 3) to evaluate properties of grout that was produced during continuous operation over an extended time period and cured in a large monolith. This report addresses the first and third objectives.

Tests were conducted on pilot-scale grout slurry, simulated waste solution, dry solids blend samples, and cured grout samples. Grout slurry collected at two points during the pilot-scale test and slurry produced in the 
laboratory were characterized by measuring rheology, drainable liquid, and penetration resistance. Cured grout samples included samples collected during the pilot-scale test and cured. in the laboratory, samples produced in the laboratory, samples obtained from tubes inserted into the monolith, and samples from cored sections of the monolith. Tests conducted on the cured samples included compressive strength, density, ultrasonic pulse velocity, leachability, and microstructural characterization. Significant findings of these tests were as follows:

- Pumping the simulated PSW grout through 150 feet of 1-in. pipe produced a more viscous slurry compared with slurry at the pump inlet.

- The properties of simulated PSW and dry blend were consistent throughout the pilot-scale test.

- There were no significant differences in the leach resistance or in the physical properties of grout samples collected at different locations within the trench. 


\section{ACKNOWLEDGMENTS}

The authors would like to acknowledge the efforts of several people who helped make this report possible. We would like to thank J. M. Allison, L. C. Brown, J. D. Herb, W. G. Richmond, A. R. Tedeschi, J. E. VanBeek, G. F. Williamson, and D. D. Wodrich of Westinghouse Hanford Company for their review, and J. M. Zama of Pacific Northwest Laboratory for word processing support.

Special thanks are extended to D. H. Mitchell for his review and guidance and to A. H. McMakin for technical editing. 


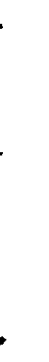




\section{CONTENTS}

SUMMARY i i i

ACKNOWLEDGMENTS

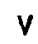

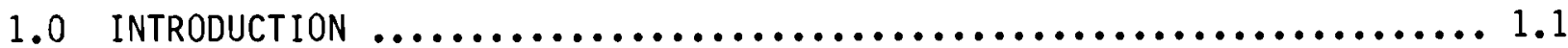

2.0 PILOT-SCALE TEST $\ldots \ldots \ldots \ldots \ldots \ldots \ldots \ldots \ldots \ldots \ldots \ldots \ldots \ldots \ldots \ldots \ldots \ldots \ldots$

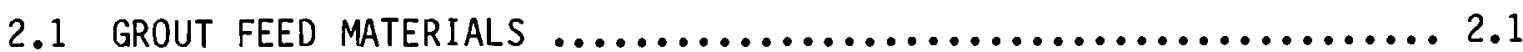

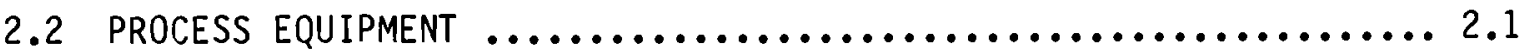

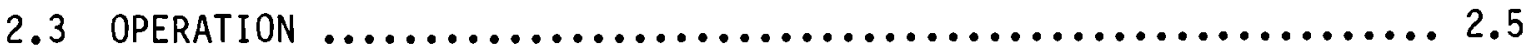

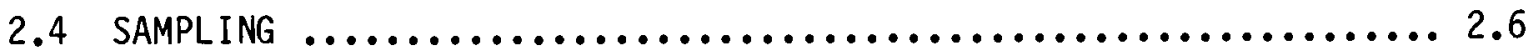

3.0 EXPERIMENTAL PROCEDURES $\ldots \ldots \ldots \ldots \ldots \ldots \ldots \ldots \ldots \ldots \ldots \ldots \ldots \ldots \ldots \ldots \ldots$

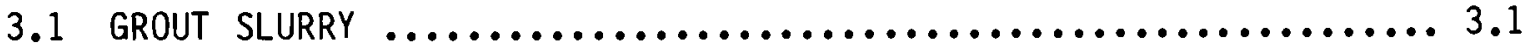

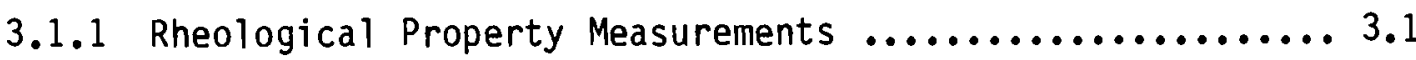

3.1.2 Density and Drainable Liquid Measurements ............ 3.2

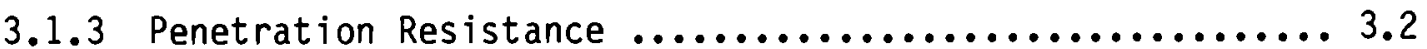

3.2 SIMULATED PHOSPHATE/SULFATE WASTE AND BLEED LIQUID ......... 3.2

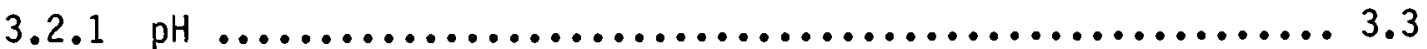

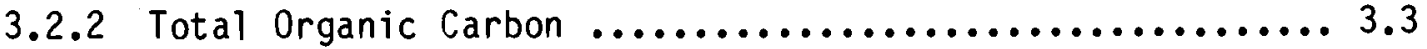

3.2.3 Extraction Procedure Toxicity ....................... 3...

3.3 ChARACTERIZATION OF DRY SOLIDS BLEND $\ldots \ldots \ldots \ldots \ldots \ldots \ldots \ldots \ldots \ldots . \ldots \ldots$

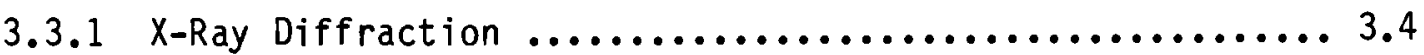

3.3 .2 Grain Size $\ldots \ldots \ldots \ldots \ldots \ldots \ldots \ldots \ldots \ldots \ldots \ldots \ldots \ldots \ldots \ldots . \ldots . \ldots \ldots$

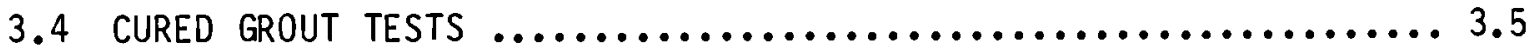

3.4 .1 Compressive Strength Testing .................... 3.5

3.4 .2 Ultrasonic Pulse Velocity ...................... 3.6

3.4 .3 Corrosivity $\ldots \ldots \ldots \ldots \ldots \ldots \ldots \ldots \ldots \ldots \ldots \ldots \ldots \ldots . \ldots \ldots$ 
3.4.4 American Nuclear Society Leach Test $\ldots . \ldots \ldots \ldots \ldots . . . . .6 .6$

3.4.5 Toxicity Characteristic Leaching Procedure ............. 3.7

4.0 RESULTS AND DISCUSSION $\ldots \ldots \ldots \ldots \ldots \ldots \ldots \ldots \ldots \ldots \ldots \ldots \ldots \ldots \ldots \ldots . . \ldots \ldots$

4.1 GROUT SLURRY PROPERTIES $\ldots \ldots \ldots \ldots \ldots \ldots \ldots \ldots \ldots \ldots \ldots \ldots \ldots . . \ldots .1$

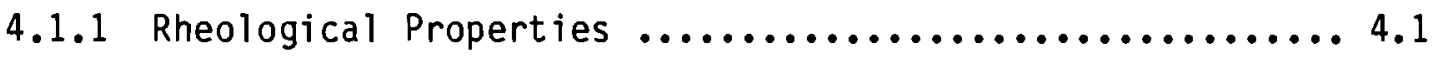

4.1 .2 Drainable Liquids $\ldots \ldots \ldots \ldots \ldots \ldots \ldots \ldots \ldots \ldots \ldots \ldots . . . \ldots .4$

4.1.3 Penetration Resistance $\ldots \ldots \ldots \ldots \ldots \ldots \ldots \ldots \ldots \ldots \ldots . \ldots .6$

4.2 CHARACTERIZATION OF SIMULATED PHOSPHATE/SULFATE WASTE AND

BLEED LIQUID $\ldots \ldots \ldots \ldots \ldots \ldots \ldots \ldots \ldots \ldots \ldots \ldots \ldots \ldots \ldots \ldots \ldots . \ldots . \ldots . \ldots$

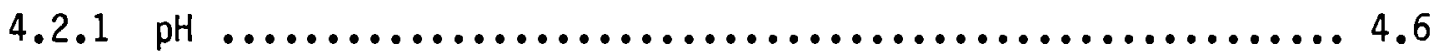

4.2.2 Extraction Procedure Toxicity $\ldots \ldots \ldots \ldots \ldots \ldots \ldots \ldots . . . . .6$

4.2.3 Chemical Analysis .............................. 4.9

4.3 CHARACTERIZATION OF DRY SOLIDS BLEND $\ldots \ldots \ldots \ldots \ldots \ldots \ldots \ldots \ldots . . \ldots \ldots$

4.3.1 X-Ray Diffraction $\ldots \ldots \ldots \ldots \ldots \ldots \ldots \ldots \ldots \ldots \ldots \ldots \ldots, 4.11$

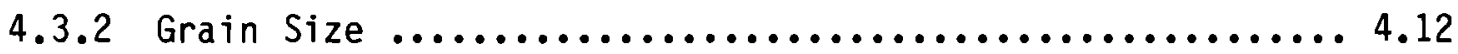

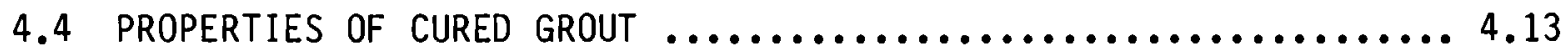

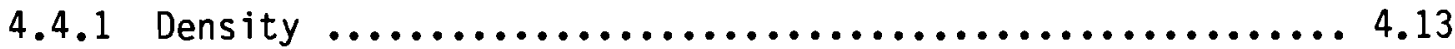

4.4.2 Compressive Strength $\ldots \ldots \ldots \ldots \ldots \ldots \ldots \ldots \ldots \ldots \ldots . . . \ldots .14$

4.4.3 Strength, Density, and Pulse Velocity $\ldots \ldots \ldots \ldots \ldots . . \ldots .16$

4.4 .4 Corrosivity $\ldots \ldots \ldots \ldots \ldots \ldots \ldots \ldots \ldots \ldots \ldots \ldots \ldots \ldots, 4.18$

4.4.5 Leach Tests ................................... 4.18

4.4.6 Toxicity Characteristic Leaching Procedure ............ 4.21

4.4.7 Microstructural Characterization $\ldots \ldots \ldots \ldots \ldots \ldots \ldots \ldots . . .21$

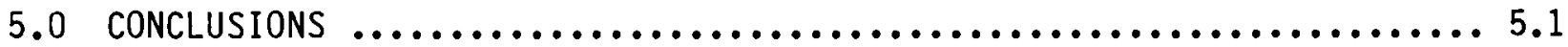

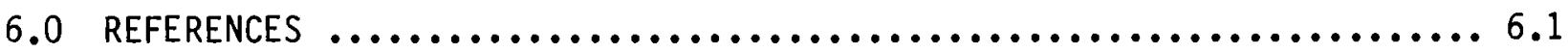




\section{FIGURES}

2.1 Schematic of the Pilot-Scale Grout Process $\ldots . \ldots . \ldots . . . \ldots \ldots . . .2 .4$

2.2 Schematic of the Pilot-Scale Grout Trench $\ldots \ldots \ldots \ldots \ldots \ldots \ldots \ldots \ldots . . .6$

2.3 Schematic of the Pilot-Scale Grout Sampler Tube $\ldots \ldots \ldots \ldots \ldots \ldots \ldots .7$

2.4 Location of Sampler Tubes Within the Monolith $\ldots \ldots \ldots \ldots \ldots \ldots \ldots . . .2 .8$

4.1 Critical Flow Rates of Pilot-Scale Grout Samples $\ldots . \ldots \ldots \ldots \ldots \ldots . . .4 .2$

4.2 Development of Penetration Resistance of PSW Grout ............... 4.7

$4.3 \mathrm{pH}$ of Pilot-Scale Bleed Liquid $\ldots \ldots \ldots \ldots \ldots \ldots \ldots \ldots \ldots \ldots \ldots \ldots . . . .6$

4.4 Changes in Bleed Liquid Concentration with Time $\ldots \ldots \ldots \ldots \ldots \ldots \ldots . . .10$

4.5 Compressive Strength of Pilot-Scale Monolith Samples as a

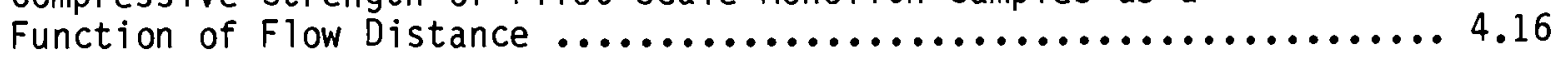

4.6 Cumulative Fraction Sodium Leached from Pilot-Scale Grout ......... 4.20

4.7 Scanning Electron Micrographs of Fracture Surfaces of Laboratory-Produced PSW Grouts $\ldots \ldots \ldots \ldots \ldots \ldots \ldots \ldots \ldots \ldots \ldots \ldots \ldots . \ldots \ldots . .22$

4.8 Scanning Electron Micrographs of Fracture Surfaces of Pilot-Scale Grouts 


\section{TABLES}

2.1 Nominal Composition of Simulated PSW Used in the

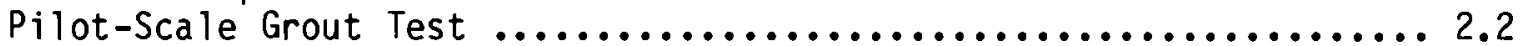

2.2 Composition of Dry Blend Used in the Pilot-Scale Grout Test ........ 2.3

2.3 Sampling Times for the Pilot-Scale Grout Test ................. 2.9

3.1 Extraction Procedure Toxicity Limits ....................... 3.4

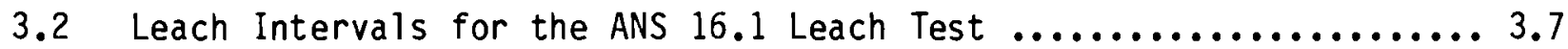

4.1 Summary of Critical Flow Rate Data for Pilot-Scale $\quad$ Grout Samples at Two Mix Ratios

4.2 Summary of Densities for Pilot-Scale Grout Samples

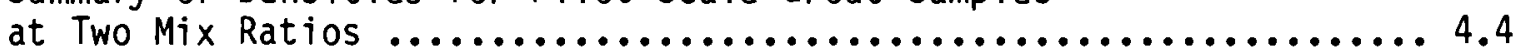

4.3 Summary of Drainable Liquid Data for Pilot-Scale

Grout Samples ............................................ 4.5

4.4 Extraction Procedure Toxicity Results for Simulated

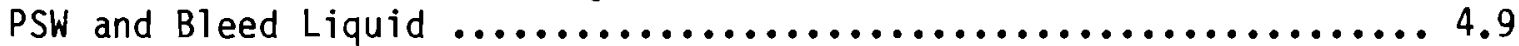

4.5 Summary of Analytical Results for Simulated PSW ................. 4.10

4.6 Relative X-Ray Diffraction Intensities of Tricalcium

Silicate, Quartz, and Clay Diagnostic Lines of

Dry Blend Samples ......................................... 4.12

4.7 Density Statistics for Pilot-Scale Grout Samples ................. 4.13

4.8 Compressive Strength Statistics for Pilot-Scale

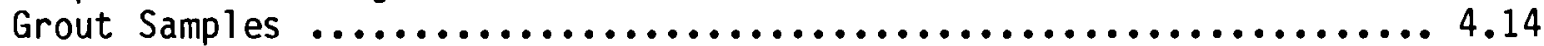

4.9 Ultrasonic Pulse Velocity Statistics for Pilot-Scale

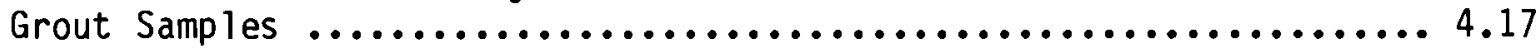

4.10 Correlation Coefficients for Compressive Strength, Density, and Pulse Velocity of PSW Grouts $\ldots \ldots \ldots \ldots \ldots \ldots \ldots \ldots \ldots \ldots \ldots \ldots \ldots, 18$

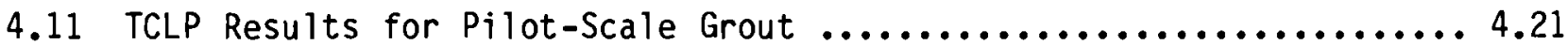




\subsection{INTRODUCTION}

A U.S. Department of Energy (DOE) program is under way at the Hanford Site near Richland, Washington, to convert the low-level fraction of selected liquid radioactive wastes to a grout form for near-surface disposal. In this report, grout is defined as a slurry, or solidified waste form, consisting of a mixture of liquid waste and grout-forming solids including portland cement, fly ash, and clays. The slurry will be pumped to near-surface disposal vaults where it will harden, thereby immobilizing the waste.

The Grout Disposal Program at Hanford is managed by Westinghouse Hanford Company (WHC) who will operate the Transportable Grout Facility (TGF). The TGF includes the Dry Materials Receiving and Handling Facility (DMRHF) and the Transportable Grout Equipment (TGE). Up to four dry solids can be received, stored, and blended at the DMRHF. The blended solids will be transported from the DMRHF to the TGE by truck. In the TGE, liquid waste will be mixed with the dry solids blend and pumped to lined, underground concrete vaults. The vaults are 125 feet long, 50 feet wide, and 34 feet deep. Approximately 88 vol\% of the vault volume will contain radioactive grout, and the top $12 \%$ will contain non-radioactive grout.

The first waste stream to be grouted is called Phosphate/Sulfate Waste from $N$ Reactor Operations (PSW). Phosphate waste results from decontamination of the reactor cooling system using a commercial decontamination solution containing phosphoric acid as the principal ingredient. The decontamination solution is neutralized with sodium hydroxide, resulting in a solution consisting primarily of sodium phosphate. Two other waste streams, sulfate waste and sandfilter backwash sludge, result from the cleanup of fuel storage basin water. The sulfate waste is produced during regeneration of ion-exchange resins with sulfuric acid followed by neutralization with sodium hydroxide. The sandfilter backwash sludge is from periodic flushing of sandfilters used to remove particulates from the water.

Pacific Northwest Laboratory (PNL) has been providing support to the Grout Disposal Program through pilot-scale tests, performance assessments, and formulation verification activities. A major pilot-scale test that produced 
22,000 gallons of simulated grout was conducted in July 1986 to assess the effectiveness of the grouting operations and the resulting grout properties. During the test, 16,000 gallons of simulated PSW waste were solidified with a four-component blend of dry solids. The solids included portland cement, fly ash, and two clays. The operation of the pilot-scale test is documented in a companion report (Fow et al. 1987).

This report describes the tests conducted on the grout samples collected from the pilot-scale test and documents the results. Comparisons are made between laboratory-produced grout samples and the pilot-scale samples. 


\subsection{PILOT-SCALE TEST}

The objectives of the pilot-scale grout test conducted in July 1986 were threefold: 1) to determine the homogeneity of the grout produced under conditions similar to those planned for the TGF, 2) to evaluate performance of candidate grout processing equipment for the TGF, and 3) to evaluate properties of grout that was produced during continuous operation over an extended time period and cured in a large monolith. This report describes the testing and results that support the first and third objectives. The second objective and detailed description of the operations of the pilot-scale test are described in a companion report (Fow et a1. 1987). This chapter summarizes some pertinent details of the pilot-scale test.

\subsection{GROUT FEED MATERIALS}

Simulated, non-radioactive PSW used in the test was prepared in batches and pumped to a 23,000-gal carbon steel storage tank. The waste was composed of equal volumes of a dilute phosphate waste and sulfate waste. A smaller, third waste stream (sandfilter backwash sludge) was also included in the sulfate waste. The solids were present in the sulfate waste in a ratio of approximately $50 \mathrm{~kg}$ per $1 \mathrm{milli}$ ion liters. The nominal composition of the simulated waste solution is shown in Table 2.1.

The dry blend used in the pilot-scale test was obtained from the DMRHF at WHC. Four dry materials were blended in batches in the proportions shown in Table 2.2. The dry blend was transported to PNL in 1000- $\mathrm{ft}^{3}$ capacity trailers. The dry blend was prepared 3 to 4 weeks prior to the pilot-scale test.

\subsection{PROCESS EQUIPMENT}

A schematic representation of the pilot-scale process is shown in Figure 2.1. The process equipment consists of four main units: a dry blend transfer and feed system, a liquid waste storage tank and transfer system, a grout mixer, and a grout pump. Piping and a lined, covered trench complete the system. 
TABLE 2.1. Nominal Composition of Simulated PSW Used in the Pilot-Scale Grout Test

\begin{tabular}{|c|c|c|}
\hline Component & $\begin{array}{l}\text { Phosphate Waste } \\
(4000-G a 1 \text { Batch) } \\
\end{array}$ & $\begin{array}{l}\text { Sulfate Waste } \\
(4000-G a 1 \text { Batch }) \\
\end{array}$ \\
\hline Tap water & $25,0001 b$ & $25,0001 \mathrm{~b}$ \\
\hline $\begin{array}{l}\text { Turco } 4512 A-17 \\
\text { (without inhibitor) }\end{array}$ & $102 \mathrm{gal}$ & 0 \\
\hline 1,3-Diethyl 2-thiorea & $1,817 \mathrm{~g}$ & 0 \\
\hline $\mathrm{Na}_{2} \mathrm{SO}_{4}$ & 0 & $68,310 \mathrm{~g}$ \\
\hline $\mathrm{As}_{2} \mathrm{O}_{3}$ & $0.061 \mathrm{~g}$ & $0.08 \mathrm{~g}$ \\
\hline $\mathrm{BaCO}_{3}$ & $1.21 \mathrm{~g}$ & $8.18 \mathrm{~g}$ \\
\hline $\mathrm{Cd}\left(\mathrm{NO}_{3}\right)_{2} \cdot 4 \mathrm{H}_{2} \mathrm{O}$ & $0.1 \mathrm{~g}$ & $2.271 \mathrm{~g}$ \\
\hline $\mathrm{Cr}\left(\mathrm{NO}_{3}\right)_{3} \cdot 9 \mathrm{H}_{2} \mathrm{O}$ & $167 \mathrm{~g}$ & $1,105 \mathrm{~g}$ \\
\hline $\mathrm{Hg}\left(\mathrm{NO}_{3}\right)_{2}$ & $0.14 \mathrm{~g}$ & $0.40 \mathrm{~g}$ \\
\hline $\mathrm{H}_{2} \mathrm{SeO}_{3}$ & $0.074 \mathrm{~g}$ & $0.098 \mathrm{~g}$ \\
\hline $\mathrm{AgNO}_{3}$ & $0.288 \mathrm{~g}$ & $1.97 \mathrm{~g}$ \\
\hline $\mathrm{CuSO}_{4} \cdot 5 \mathrm{H}_{2} \mathrm{O}$ & $4.088 \mathrm{~g}$ & $18.2 \mathrm{~g}$ \\
\hline $\mathrm{Fe}\left(\mathrm{NO}_{3}\right)_{3} \cdot 9 \mathrm{H}_{2} \mathrm{O}$ & $17,411 \mathrm{~g}$ & $1,696 \mathrm{~g}$ \\
\hline $\mathrm{Fe}_{2}\left(\mathrm{SO}_{4}\right)_{3}$ & $1,968 \mathrm{~g}$ & $24,224 \mathrm{~g}$ \\
\hline $\mathrm{MnSO}_{4} \cdot \mathrm{H}_{2} \mathrm{O}$ & $999 \mathrm{~g}$ & $115 \mathrm{~g}$ \\
\hline $\mathrm{ZnSO}_{4} \cdot 7 \mathrm{H}_{2} \mathrm{O}$ & $47 \mathrm{~g}$ & $2,574 \mathrm{~g}$ \\
\hline $\mathrm{Pb}\left(\mathrm{NO}_{3}\right)_{2}$ & $1.075 \mathrm{~g}$ & $19.7 \mathrm{~g}$ \\
\hline $\mathrm{Ni}\left(\mathrm{NO}_{3}\right)_{2} \cdot 6 \mathrm{H}_{2} \mathrm{O}$ & $139 \mathrm{~g}$ & $227 \mathrm{~g}$ \\
\hline $\mathrm{Ca}\left(\mathrm{NO}_{3}\right)_{2} \cdot 4 \mathrm{H}_{2} \mathrm{O}$ & $197 \mathrm{~g}$ & 0 \\
\hline $\mathrm{CaSO}_{4} \cdot 0.5 \mathrm{H}_{2} \mathrm{O}$ & 0 & $1,105 \mathrm{~g}$ \\
\hline $\mathrm{KNO}_{3}$ & 0 & $303 \mathrm{~g}$ \\
\hline $\mathrm{A} 1\left(\mathrm{NO}_{3}\right)_{3} \cdot 9 \mathrm{H}_{2} \mathrm{O}$ & 0 & $3,634 \mathrm{~g}$ \\
\hline $\mathrm{NaF}$ & $394 \mathrm{~g}$ & $1,332 \mathrm{~g}$ \\
\hline $\mathrm{NaCl}$ & $545 \mathrm{~g}$ & $999 \mathrm{~g}$ \\
\hline $\mathrm{NaOH}$ flakes & $535.2 \mathrm{~kg}$ & $22.2 \mathrm{~kg}$ \\
\hline Tap water & to 4000 -gal level & to $4000-$ gal leve 1 \\
\hline
\end{tabular}


TABLE 2.2. Composition of Dry Blend Used in the

Pilot-Scale Grout Test

\begin{tabular}{lc} 
Component & Amount, wt \\
\hline Type I/ I I Portland Cement & 41 \\
Class F Fly Ash & 40 \\
Attapulgite Clay & 11 \\
Illitic Clay & 8
\end{tabular}

Dry blend was transferred by vacuum from the trucks to a storage bin that was located directly above the active bin. During production, the dry blend was gravimetrically fed using an auger to an 18-in. vibrating screen and into the grout mixer.

The simulated waste solution was pumped from the storage tank to the grout mixer using a centrifugal pump. The tank contained a recirculation loop to keep precipitates suspended during the run. The flow rate of the waste was controlled with a gate valve. To minimize foaming in the grout slurry, tributyl phosphate was also added to the mixer at a rate equal to 0.02 vol\% of the waste.

The mixer was a Teledyne Readco(a) 5.25-in. twin-shaft continuous processor. The dry blend and waste entered the top of the mixer and grout slurry discharged at the opposite end into a surge tank right above the pump inlet. Mixing was conducted at $250 \mathrm{rpm}$.

The grout transfer system consisted of a grout pump and steel piping. The grout pump consisted of a two-stage progressive cavity pump with an ethylenepropylene-diene-monomer (EPDM) stator. The pump speed was manually controlled to maintain a constant grout level in the surge tank. Grout was pumped through $1-i n$. Schedule 40 carbon steel pipe to the trench. The total length of the piping was approximately 150 feet.

A schematic representation of the trench is shown in Figure 2.2. The overall top dimension of the trench was $20 \mathrm{ft}$ by $60 \mathrm{ft}$. The sides were sloped $45^{\circ}$ to a total depth of $8 \mathrm{ft}$. The capacity of the trench was $30,000 \mathrm{gallons}$.

(a) Teledyne Readco, York, PA. 
Dry Blend From

Storage/Feed Trailer

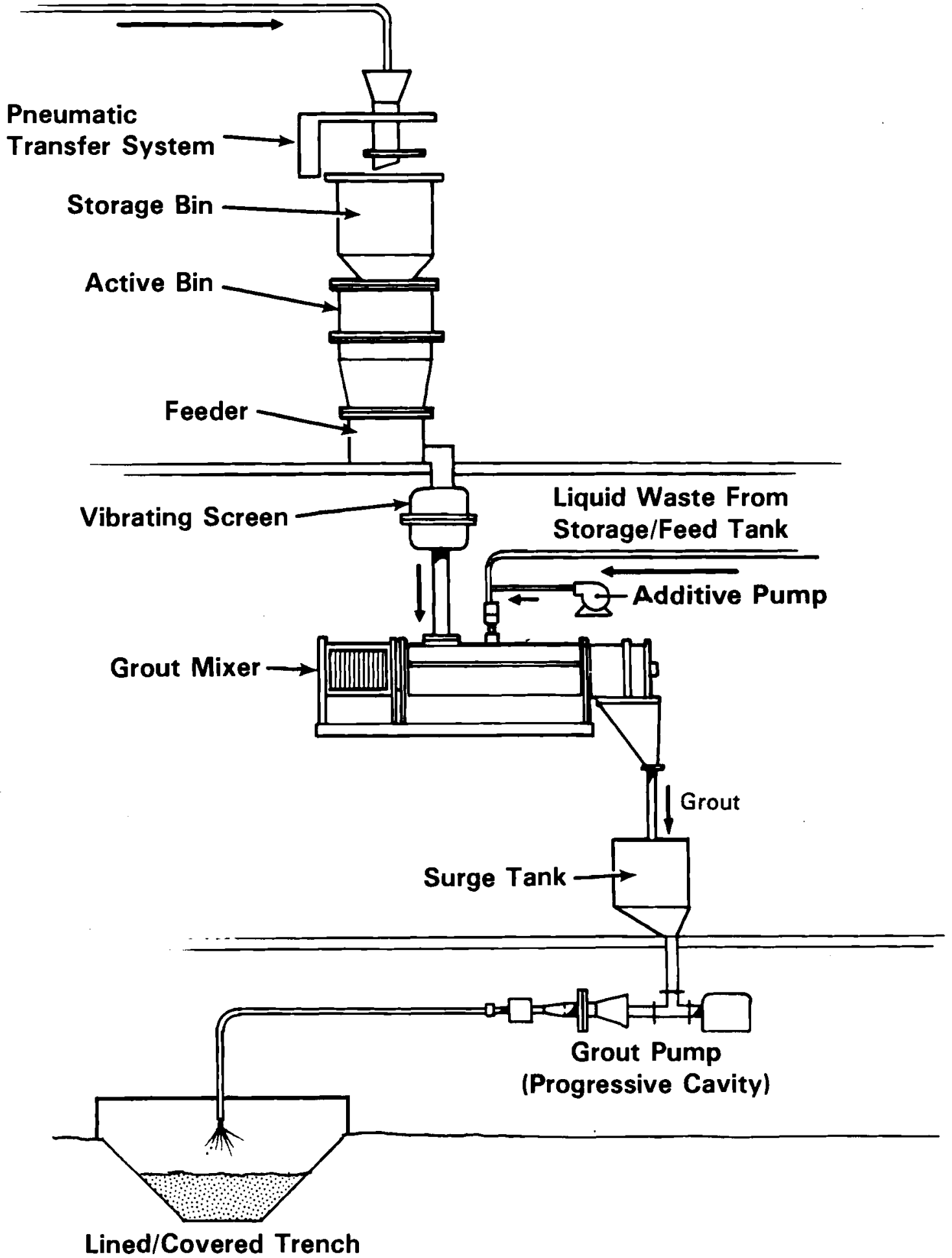

FIGURE 2.1. Schematic of the Pilot-Scale Grout Process 


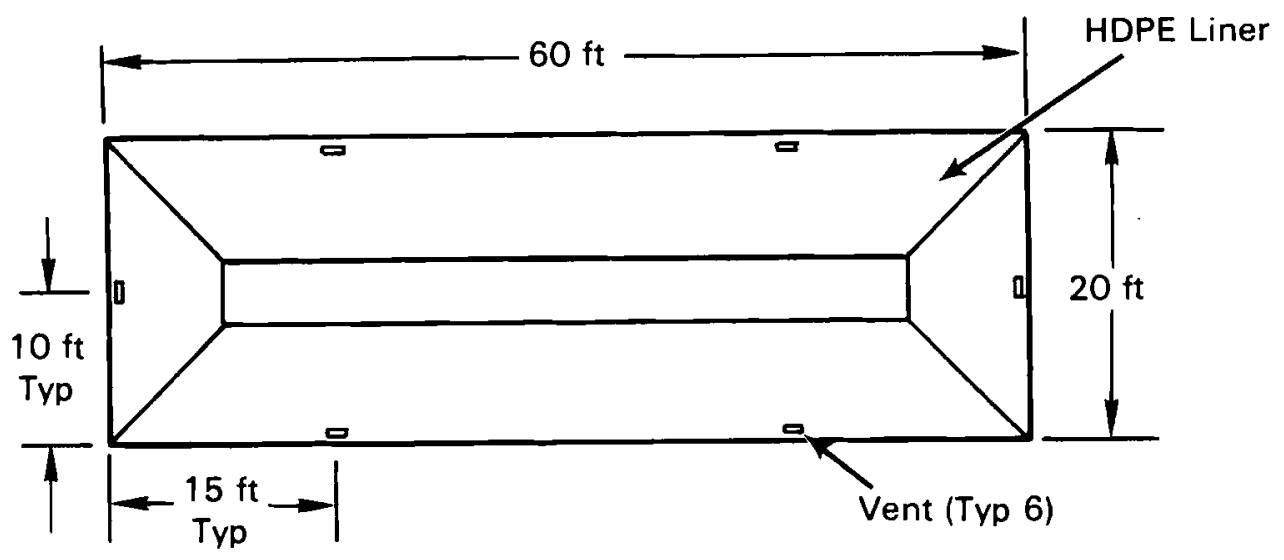

Plan

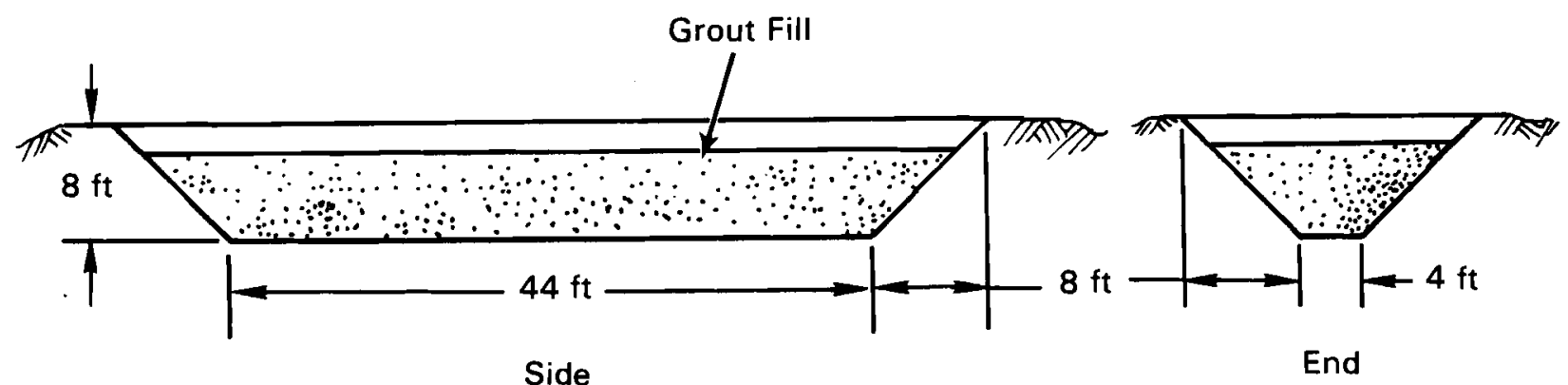

FIGURE 2.2. Schematic of the Pilot-Scale Grout Trench

The trench was lined with 60-mi1-thick high-density polyethylene. A woodenframed cover was constructed over the trench and covered with 20-mi 1 polyvinyl chloride to act a vapor barrier. The discharge nozzle was located at one end of the trench, resulting in grout flowing 50 feet down the trench.

\subsection{OPERATION}

The pilot-scale test was conducted over a 2-day period with about 22,000 gallons of grout produced. The total production time was about 25 hours. During the first part of the test, problems with the dry blend feed system caused flooding in the mixer and subsequent plugging resulting in a down 
time of about 7 hours. Throughout the remainder of the run, downtimes were limited to 30 minutes or less (due to solids feeding problems or changing dry blend supply trailers).

At the beginning of the test, the ratio of dry solids blend to the simulated PSW (mix ratio) was $7.5 \mathrm{lb} / \mathrm{gal}$. Preliminary rheological evaluations of the initial grouts indicated that the grout slurry thickened as it was pumped to the trench (see Section 4.4.1). Because of the thickening, the grout slurry was flowing under laminar conditions at some locations within the pipe; consequently, a decision was made to decrease the mix ratio to 7.0 1b/gal. After a total of six hours of production, the mix ratio was increased to $7.21 \mathrm{~b} / \mathrm{ga} 1$ where it remained for the remainder of the test.

At the conclusion of the test, the level of grout beneath the discharge nozzle was $6.3 \mathrm{ft}$; at the farthest point in the trench, the level was $5.2 \mathrm{ft}$. This difference corresponded to an average flow angle of $1.5^{\circ}$. Drainable liquid, estimated to be 1600 gallons, was present over approximately half of the monolith surface area immediately after the test. The level of liquid decreased with time, and after 30 days all the liquid had readsorbed into the grout. During curing, the temperature near the discharge end of the monolith peaked at $66^{\circ} \mathrm{C}$ after 3 days. Additional details of the test can be found in Fow et al. (1987).

\subsection{SAMPLING}

Several samples of grout slurry, dry blend, and simulated PSW were collected during the run to statistically determine homogeneity of both the starting materials and the resultant grout. Specially constructed sampling tubes were used to obtain samples of cured grout. The tubes, shown schematically in Figure 2.3, were inserted into the monolith prior to hardening of the grout slurry. The sampler tubes consisted of schedule 40 PVC pipe within a carbon steel outer tube. The bottom of the assembly was sealed with 0 -rings to prevent grout slurry from entering the annulus. As the tubes were inserted, grout slurry flowed into the inner tube. The tubes were placed at predetermined locations within the monolith, as shown in Figure 2.4. Ten tubes were inserted when the grout depth was about three feet; the remainder were inserted 


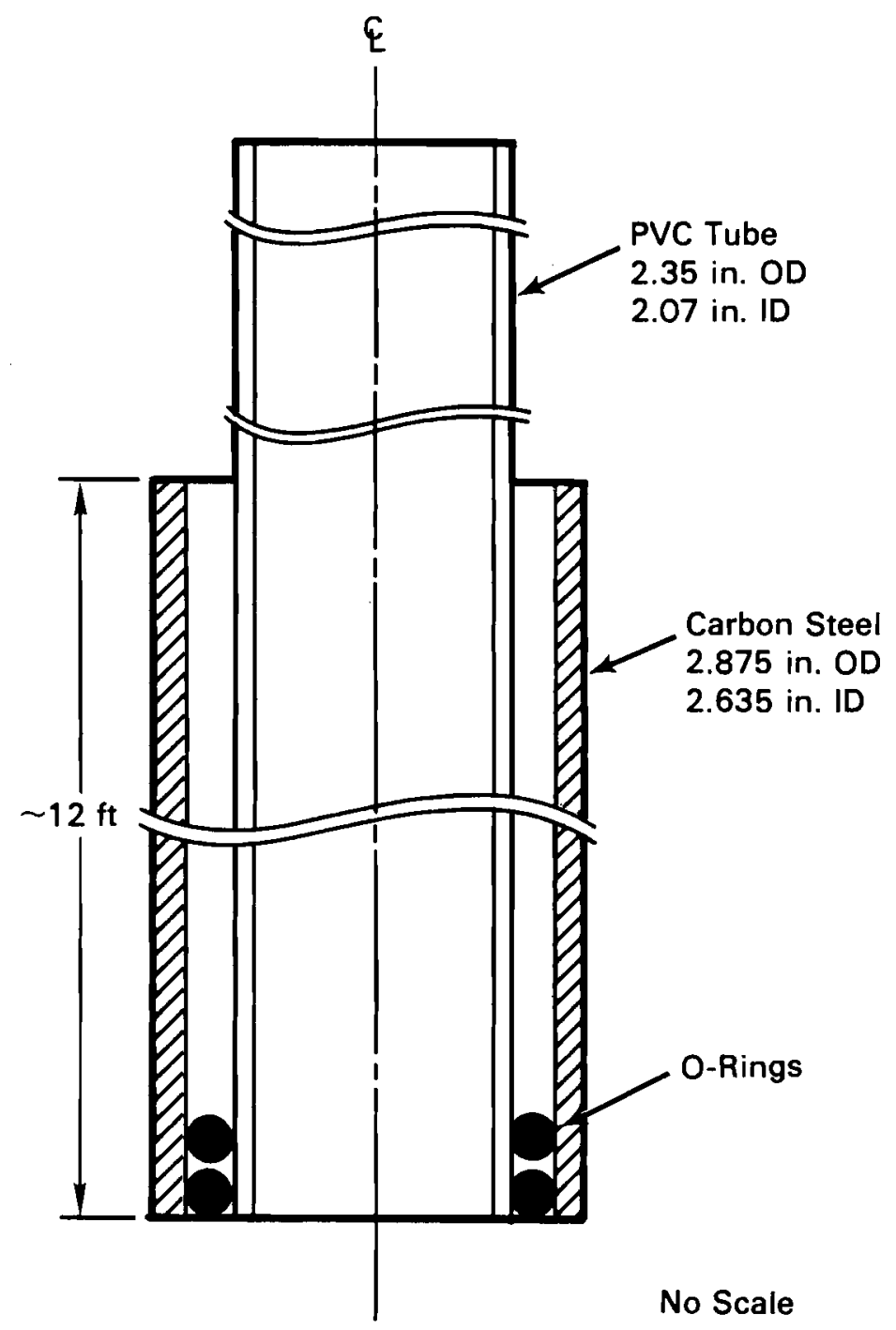

FIGURE 2.3. Schematic of the Pilot-Scale Grout Sampler Tube

at the end of the test. The grout was al lowed to cure in the tubes for 28 days. Removal was accomplished by twisting the inner tube, thereby breaking off the grout at the bottom, and removing the samples.

Samples of grout slurry, simulated PSW, and dry blend were collected according to the schedule shown in Table 2.3. In addition to the hourly times listed in the table, samples were taken at time periods that corresponded to the time at which the average increase in grout depth in the trench was 6 in. The latter time periods were called "critical sampling times" and are denoted 

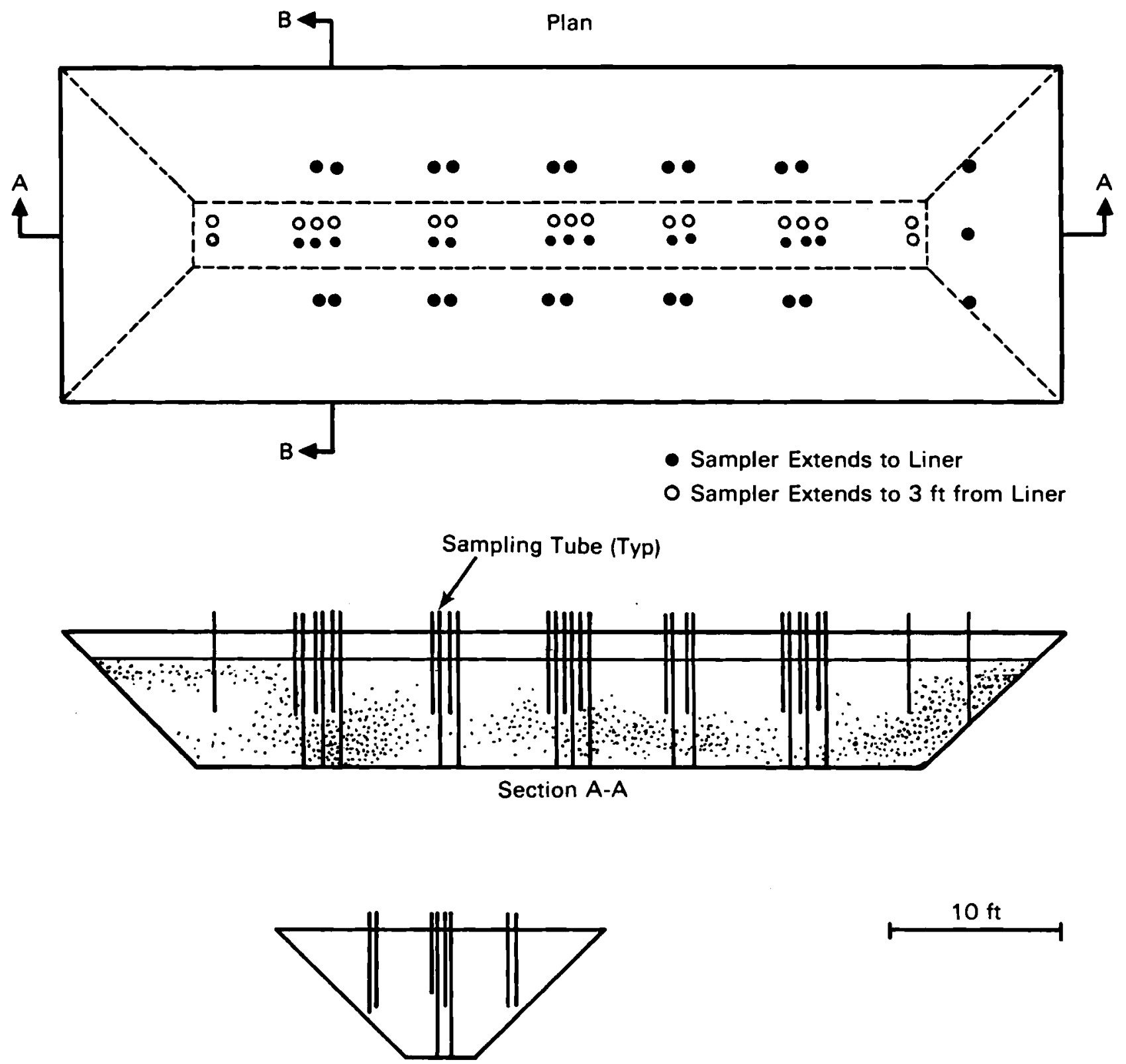

Section B-B

FIGURE 2.4. Location of Sampler Tubes Within the Monolith 
TABLE 2.3. Sampling Times for the Pilot-Scale Grout Test

\begin{tabular}{|c|c|c|c|}
\hline $\begin{array}{c}\text { Interval } \\
\text { Number }\end{array}$ & $\begin{array}{l}\text { Production } \\
\text { Time, min. }\end{array}$ & & Comments \\
\hline 1 & $24(a)$ & Mix ratio & $7.51 \mathrm{~b} / \mathrm{ga} 1$ \\
\hline 2 & $78^{(a)}$ & Mix ratio & $7.01 \mathrm{~b} / \mathrm{ga} 1$ \\
\hline 3 & 120 & & \\
\hline 4 & $138^{(a)}$ & & \\
\hline 5 & 180 & & \\
\hline 6 & $216^{(a)}$ & & \\
\hline 7 & 240 & & \\
\hline 8 & $306^{(a)}$ & & \\
\hline 9 & 360 & & \\
\hline 10 & $408^{(a)}$ & & \\
\hline 11 & 480 & & \\
\hline 12 & $522^{(a)}$ & Mix ratio & $7.21 \mathrm{~b} / \mathrm{ga} 1$ \\
\hline 13 & 600 & & \\
\hline 14 & $660^{(a)}$ & & \\
\hline 15 & 720 & & \\
\hline 16 & $780^{(a)}$ & & \\
\hline 17 & 840 & & \\
\hline 18 & 900 & & $\cdot$ \\
\hline 19 & $960^{(a)}$ & & \\
\hline 20 & 1020 & Duplicate & sample collected \\
\hline 21 & 1080 & & \\
\hline 22 & $1140^{(\mathrm{a})}$ & Duplicate & sample collected \\
\hline 23 & 1200 & & \\
\hline 24 & 1260 & & \\
\hline 25 & $1320^{(a)}$ & & \\
\hline 26 & 1380 & & \\
\hline 27 & 1440 & & \\
\hline
\end{tabular}

(a) Denotes the critical sampling times, corresponding to an average increase in grout depth in the trench of 6 in. 
by an asterisk in the table. Duplicate samples were collected at two time periods to estimate experimental error in the subsequent testing. Rheological property measurements were conducted on all the grout slurry samples collected. Tests on cured grout samples and characterization of the dry blend and PSW samples were conducted only on those samples collected at the critical sampling times.

Grout slurry samples were obtained from the grout surge tank and at the discharge nozzle to the trench. The slurry was collected in plastic pails and then poured into appropriate sample containers for determining density, rheological properties, compressive strengths, drainable liquids, and penetration resistance.

Dry blend samples were collected at the storage bin of the dry blend transfer system. Simulated PSW was collected at the mixer inlet for use in pH determination, EP toxicity testing, and chemical analysis. Samples of dry blend and PSW, collected at the critical sampling times, were used to produce and test grouts in the laboratory. 


\subsection{EXPERIMENTAL PROCEDURES}

This chapter describes the experimental procedures used to test the grout slurry, the simulated waste solution and bleed liquid, the dry solids blend, and cured grout samples.

\subsection{GROUT SLURRY}

Grout slurry samples were collected at two locations during the pilotscale test: at the surge tank leading to the pump and at the discharge nozzle to the trench. In addition, grout samples were also produced in the laboratory with waste solution and dry blend samples collected during the test. The properties of grout slurry measured included the rheological properties, density, drainable liquid, and set time.

\subsubsection{Rheological Property Measurements}

The rheological properties of grout samples were determined with a Fann(a) Model $35 \mathrm{~A}$ viscometer. The Fann viscometer employs six preset speeds (3, 6, $100,200,300$, and $600 \mathrm{rpm})$. Grout slurry is contained in the annular space between two cylinders. The outer cylinder (or rotor) is rotated by means of a motor at constant velocity (shear rate). The rotation of the rotor in the grout produces a torque on the inner cylinder (bob). A torsion spring attached to the bob restrains movement. The dial attached to the spring indicates the torque imparted through the grout as the rotor is rotated. The dial is calibrated to read shear stress directly in units of $1 b_{f} / 100 \mathrm{ft}^{2}$. Rheological measurements on grout are conducted using the highest four speeds of the instrument, starting at $600 \mathrm{rpm}$ and working down to $100 \mathrm{rpm}$.

The shear rate/shear stress values are used to calculate flow properties according to the power law model described by Smith (1976). In this analysis, turbulent flow is assumed to begin at a Reynolds number of 2100 . Grout is required to be pumped in turbulent flow to minimize particle settling that could result in flow restrictions. The parameter used in this report to describe the flow properties of grout slurries is the critical flow rate (CFR).

(a) Fann Instrument Corporation, Houston, TX. 
The CFR is defined as the minimum flow rate that must be maintained through a given pipe diameter such that the calculated Reynolds number is 2100.

\subsubsection{Density and Drainable Liquid Measurements}

The density of freshly prepared grout slurry was determined by pouring approximately $240 \mathrm{~mL}$ of grout into a $250-\mathrm{mL}$ graduated cylinder and measuring the weight and the actual volume poured. The same sample was used to determine volume of drainable liquids and shrinkage as the grout solids settled and the slurry cured. The presence of drainable liquids is undesirable because the liquid must be recycled back into the grout process.

\subsubsection{Penetration Resistance}

Penetration resistance measurements were conducted on grout samples to determine the relative rate of setting, or hardening. The tests followed the method outlined in the American Society of Testing and Materials (ASTM) procedure C403-85 (ASTM 1985). Grout slurry samples were collected and stored in plastic containers $6.5 \mathrm{in}$. in diameter and filled to a depth of greater than 6 in. The samples were cured under ambient conditions. An Acme Penetrometer $(a)$ equipped with a hydraulic pressure gauge and six removable needles was used. The needles have surface areas between 1 and $1 / 40 \mathrm{in}^{2}$. Pressure was applied gradually and uniformly as the needle penetrated the grout to a depth of 1 inch in 10 seconds. The maximum pressure was recorded and the penetration resistance was calculated from the pressure and the surface area of the needle. Several measurements were taken on each sample throughout the 28 -d period following the test.

\subsection{SIMULATED PHOSPHATE/SULFATE WASTE AND BLEED LIQUID}

Samples of simulated waste were collected according to the sampling schedule discussed in Section 2.4. Samples of bleed liquid from the grout trench were collected three times per week for 28 days after the pilot-scale test. Aliquots of the waste samples were immediately measured for $\mathrm{pH}$ and the

(a) Humboldt Manufacturing Company, Chicago, IL. 
remainder stored for further analysis of total organic carbon and extraction procedure (EP) toxicity. Bleed liquid samples were refrigerated until tested.

\subsection{1 pH (Corrosivity)}

According to the U.S. Environmental Protection Agency (U.S. EPA) guidelines governing liquid wastes, a waste is considered corrosive if it is aqueous and has a pH of less than or equal to 2 or greater than or equal to 12.5 (U.S. EPA 1982). The $\mathrm{pH}$ of samples of simulated waste was determined immediately after sampling using a Model 135 Corning(a) $\mathrm{pH} / \mathrm{ion}$ meter. The $\mathrm{pH}$ meter was calibrated with $\mathrm{pH} 7$ and $\mathrm{pH} 10$ buffer solutions. The $\mathrm{pH}$ of the bleed liquid samples were determined within one week after collection using the same instrument and procedures as for the waste.

\subsubsection{Total Organic Carbon}

The organic carbon content of simulated PSW and the bleed liquid was measured using a Xertex-Dohrmann (b) Model DC-80 Analyzer. This instrument employs ultraviolet-promoted, low-temperature oxidation with a non-dispersive infrared (NDIR) detector. Ten milliliters of sample were pipetted into a glass vial, acidified with 4 vol\% Ultrex $\mathrm{HCl}$ and refrigerated until tested. Reported values are averages of at least three $200 \mu \mathrm{L}$ injections.

\subsubsection{Extraction Procedure Toxicity}

The extraction procedure (EP) toxicity procedure is a laboratory test designed to simulate the leaching conditions a waste may encounter in a sanitary landfill (U.S. EPA 1982). In the test, a representative sample of waste is extracted with a solution of deionized water and acetic acid maintained at a $\mathrm{pH}$ of 5. The procedure contains several preparation steps that are dependent on the nature of the waste. If the waste is liquid and contains solid materials, the waste is filtered; if the solids fraction is greater than $0.5 \mathrm{wt} \%$, the solid phase is extracted with the $\mathrm{pH} 5$ solution. After extraction, the filtered extract is combined with the initial filtrate and submitted for analysis. If the waste contains less than 0.5 wt\% solids, the solids are discarded and

(a) Corning Scientific Instruments, Medfield, MA.

(b) Xertex Corporation, Santa Clara, CA. 
the liquid phase is treated as the extract and submitted for analysis. This was the case with the simulated PSW and bleed liquid (see Section 4.2.3). The extract was analyzed for the eight metals listed in Table 3.1. Inductively coupled argon plasma spectroscopy was used to analyze for $\mathrm{As}, \mathrm{Ba}, \mathrm{Cd}, \mathrm{Cr}$, and $\mathrm{Pb}$. Atomic adsorption spectroscopy was used for $\mathrm{As}, \mathrm{Ag}$, Se, and $\mathrm{Hg}$.

\subsection{CHARACTERIZATION OF DRY SOLIDS BLEND}

The dry solids blend used in the pilot-scale test was produced at the DMRHF at WHC. The samples that were collected during the pilot-scale test were characterized by $X$-ray diffraction (XRD) and grain size measurements to determine homogeneity.

\subsubsection{X-Ray Diffraction}

$X$-ray diffraction was used to determine whether significant mineralogical differences in the dry blend occurred during the pilot-scale test. Thirteen samples of dry blend collected at the critical sampling times (see Section 2.4) were analyzed with a Philips(a) APD 3600 automated powder diffractometer. The powdered samples were packed in standard X-ray powder mounts with reasonable

TABLE 3.1. Extraction Procedure Toxicity Limits

\begin{tabular}{cc} 
Metal & $\begin{array}{c}\text { Maximum } \\
\text { Concentration, } \mathrm{mg} / \mathrm{L}\end{array}$ \\
\cline { 2 - 2 } $\mathrm{As}$ & 5 \\
$\mathrm{Ba}$ & 100 \\
$\mathrm{Cd}$ & 1 \\
$\mathrm{Cr}$ & 5 \\
$\mathrm{~Pb}$ & 5 \\
$\mathrm{Hg}$ & 0.2 \\
$\mathrm{Se}$ & 1 \\
$\mathrm{Ag}$ & 5
\end{tabular}

(a) Philips Electronics, Mahwah, NJ. 
care taken to obtain uniform density. CuKc radiation obtained with a graphite monochrometer was used at $40 \mathrm{kV}$ and $25 \mathrm{ma}$. The scan rate was $1.1^{\circ} 20 / \mathrm{min}$ over an interval of $5^{\circ}$ to $70^{\circ} 20$.

\subsubsection{Grain Size}

Samples of dry blend were characterized for grain size according to ASTM C786-76 (ASTM 1983). Approximately $10 \mathrm{~g}$ of dry blend, weighed to the nearest $0.01 \mathrm{~g}$, were placed into a 3-in. diameter U.S.A. Standard 200 mesh sieve with a wall height of $3.25 \mathrm{in}$. The sample was gently wetted with spray from a nozzle and then the pressure was increased to $10 \mathrm{psi}$. The sample was sprayed continuously for 1.5 minutes while moving the screen under the nozzle in a circular motion. The distance between the screen and the nozzle tip was $2.5 \mathrm{in}$. After the sample and sieve were rinsed with distilled water, the sieve was dried in an oven at $105^{\circ} \mathrm{C}$. The sieve was cooled and the residue carefully removed with a plastic brush. The residue was weighed to the nearest $0.01 \mathrm{~g}$.

\subsection{CURED GROUT TESTS}

Properties of cured grout samples were determined using various test methods. Tests were conducted using grout samples collected during the pilot-scale test, samples from the tubes that were inserted into the monolith, samples produced in the laboratory, and on core samples from the monolith.

\subsubsection{Compressive Strength Testing}

Grout slurry collected during the run and slurry produced in the laboratory were poured into 2-in. diameter cylindrical molds, capped, and allowed to cure for a specified time period. After curing, the grout samples were removed from the molds and the ends cut with an abrasive saw to provide flat, parallel faces. Samples of grout from the monolith were obtained by cutting the tubes containing grout, removing the grout from the tubes, and milling the samples on a lathe to 2-in. diameter. The length-to-diameter ratio of all the samples was 2. Testing was conducted with an Instron(a) test machine at a constant cross-head speed of $0.05 \mathrm{in.} / \mathrm{min}$. The load-to-failure was determined from the

(a) Instron Corporation, Canton, MA. 
maximum point of a load-deformation curve. Compressive strength values were calculated by dividing the maximum load by the cross-sectional surface area of the cylinders.

\subsubsection{Ultrasonic Pulse Velocity}

The pulse velocity of propagation of compressional waves through grout

samples was determined with a James (a) Sonic Velocity Meter (V-Meter), Model 4902, according to the test method outlined in ASTM C 597-83 (ASTM 1983). In this method, pulses of compressional waves, generated by an electroacoustical transducer, traverse through a sample and are received by a second transducer. The transit time is measured electronically and the velocity is determined by the knowledge of this time and the transit distance. The pulse velocities of the grout samples were measured on cylindrical samples with sawcut faces. The transducers were positioned on the faces using water as a coupling medium. The transit time was read from the $V$-meter and velocity was determined by dividing the length of the samples by the transit time.

\subsubsection{Corrosivity}

The corrosivity of grout samples from the pilot-scale monolith was determined using the Washington Department of Ecology (WDOE) Method 83-13 (WDOE 1984). Fifty grams grout were combined with an equal weight of distilled water and agitated for 30 minutes. The $\mathrm{pH}$ of the solution was measured after removing the solids from the mixture. According to this procedure, a solid is considered corrosive if the solution has a $\mathrm{pH}$ of less than or equal to 2 , or greater than or equal to 12.5 .

\subsubsection{American Nuclear Society (ANS 16.1) Leach Test}

The ANS 16.1 leach test (ANS 1984) was applied to 22 grout samples from the sampler tubes to determine whether position within the monolith had any effect on the leachability. The test is an intermittent leachate exchange test designed to simulate a dynamic system. The leachate exchange intervals are shown in Table 3.2.

(a) James Instruments Incorporated, Chicago, IL. 
TABLE 3.2. Leach Intervals for the ANS 16.1 Leach Test

\begin{tabular}{|c|c|c|}
\hline $\begin{array}{c}\text { Interval } \\
\text { No. } \\
\end{array}$ & $\begin{array}{c}\text { Time } \\
\text { Between } \\
\text { Intervals } \\
\end{array}$ & $\begin{array}{c}\text { Cumu lat i ve } \\
\text { Time }\end{array}$ \\
\hline 1 & $2 \mathrm{~h}$ & $2 \mathrm{~h}$ \\
\hline 2 & $5 \mathrm{~h}$ & $7 \mathrm{~h}$ \\
\hline 3 & $17 \mathrm{~h}$ & $1 \mathrm{~d}$ \\
\hline 4 & $24 \mathrm{~h}$ & $2 d$ \\
\hline 5 & $24 \mathrm{~h}$ & $3 \mathrm{~d}$ \\
\hline 6 & $24 \mathrm{~h}$ & $4 d$ \\
\hline 7 & $24 \mathrm{~h}$ & $5 d$ \\
\hline 8 & $14 \mathrm{~d}$ & $19 \mathrm{~d}$ \\
\hline 9 & $28 d$ & $47 \mathrm{~d}$ \\
\hline 10 & $42 \mathrm{~d}$ & $89 \mathrm{~d}$ \\
\hline
\end{tabular}

All samples used in this test were right circular cylinders, milled on a lathe to dimensions of $2 \mathrm{in.}(5.08 \mathrm{~cm})$ diameter by $1 \mathrm{in} .(2.54 \mathrm{~cm}) \mathrm{high}$. The samples, with a surface area of approximately $81 \mathrm{~cm}^{2}$, were suspended by a Teflon (a) support in $810 \mathrm{~mL}$ of deionized water within a polyethylene container. After the elapsed time periods, the samples were removed from the leachate and placed into containers containing fresh leachant. The $\mathrm{pH}$ of the leachate was measured immediately after removing the sample. Aliquots of leachate were acidified with 1 vol\% nitric acid and submitted for cation analysis by inductively coupled argon plasma atomic emission spectroscopy (ICP).

\subsubsection{Toxicity Characteristic Leaching Procedure (TCLP)}

The proposed TCLP (U.S. EPA 1986) was conducted on 22 pilot-scale monolith samples. The grout samples were crushed and sieved through a screen with 3/8-in. openings. One hundred grams of grout that had passed through the screen and 2000 grams of extraction fluid were added to 2-liter glass bottles.

(a) E. I. duPont deNemours \& Co. Inc., Wilmington, DE. 
The extraction fluid was an acetic acid solution with a pH of 2.88. The vessels were tumbled in a rotary extractor at $30 \mathrm{rpm}$ for 18 hours. Following the extraction, the solution was filtered and aliquots collected and submitted for chemical analysis. 


\subsection{RESULTS AND DISCUSSION}

This section presents results of tests on pilot-scale grout slurry, simulated waste solution, dry solids blend samples, and cured grout samples. Grout slurry collected at two points during the pilot-scale test and slurry produced in the laboratory were characterized by measuring rheology, drainable liquid, and penetration resistance. Cured grout samples included samples collected during the pilot-scale test and cured in the laboratory, samples produced in the laboratory, samples obtained from the tubes inserted into the monolith, and cored sections of the monolith. Tests conducted on the cured samples included compressive strength, density, sonic velocity, leachability, and microstructural characterization.

\subsection{GROUT SLURRY PROPERTIES}

Grouts to be processed in the TGF are formulated to allow pumping up to 3000 feet through 2-in. diameter pipe at flow rates of up to $70 \mathrm{gpm}$. The grouts must be pumped in turbulent flow to minimize particle settling and the potential for plugging the pipe. Minimizing the particle settling and the subsequent separation of a liquid phase is also desirable because any liquid present on the grout surface must be recycled. The setting rate of the grout slurry, although not a major criterion of grouted waste disposal, is important in assuring that the grout will set in a reasonable period of time. These parameters were addressed by measuring rheological properties, drainable liquids, and penetration resistance on three sets of grout slurry samples. One set of samples was produced in the laboratory with dry blend and simulated waste samples collected during the pilot-scale test. The remaining two sets of samples were obtained during the pilot-scale test, one from the surge tank just above the pump, and the other from the pipe discharge to the trench.

\subsubsection{Rheological Properties}

To assure that the grout was being pumped in turbulent flow, samples of grout slurry were subjected to rheological property tests and density measurements. The results from slurry density and shear rate/shear stress measurements were used to calculate the critical flow rate of the various grout slurry 
samples. Critical flow rates were calculated using the equations given by Smith (1976) and a laminar-to-turbulent transition point at a Reynolds number of 2100 .

Figure 4.1 shows the critical flow rates of grout slurry samples collected at the various time periods of the pilot-scale test. During the test, the mix ratio was changed from $7.5 \mathrm{lb} / \mathrm{gal}$ at the first sampling time, to $7.0 \mathrm{lb} / \mathrm{gal}$ and finally to $7.2 \mathrm{lb} / \mathrm{gal}$ as depicted in the figure. In general, it is evident that the critical flow rates of the nozzle samples were higher than those of the surge tank samples, indicating that the grout became thicker as a result of the pumping and flow in the piping. The thickening was due to the increased

Mix Ratio

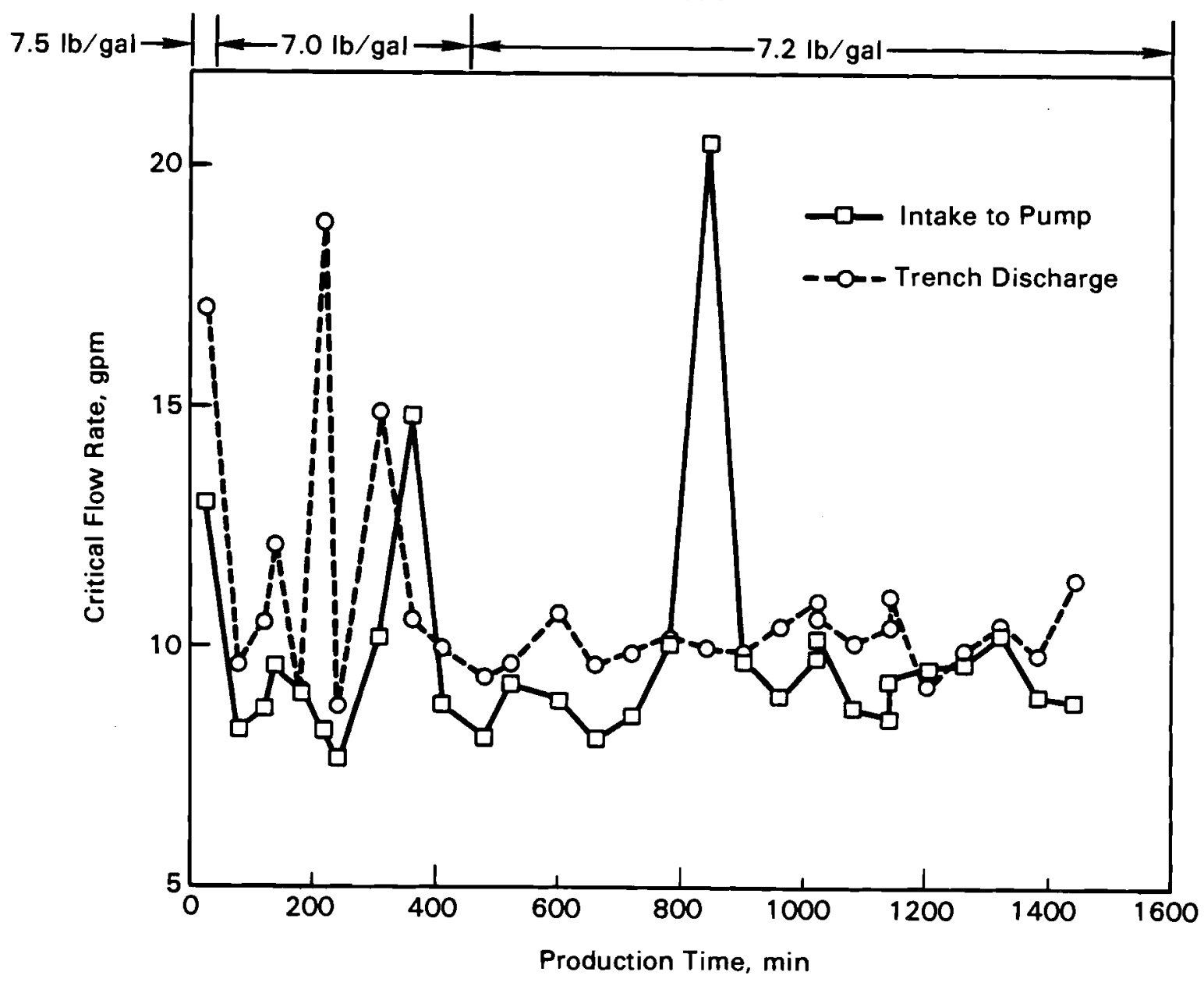

FIGURE 4.1. Critical Flow Rates of Pilot-Scale Grout Samples 
shear that was imparted on the slurry which resulted in greater dispersion of the attapulgite clay crystals. This phenomenon has been described elsewhere (Lokken et a1. 1987). With the exception of a few data points, the critical flow rate of the pilot-scale grout slurry was below the operating flow rate of $15 \mathrm{gpm}$, indicating turbulent flow.

Grouts were also prepared and tested in the laboratory with dry blend and simulated waste solution after the pilot-scale test. Dry blend and waste solution collected at the critical sampling times (see Section 2.4) were used to produce the grouts. The critical flow rates of the laboratory-produced grout slurries are compared with the pilot-scale samples in Table 4.1. The first column under each category summarizes all the data collected, while the numbers in parentheses exclude the outliers shown in Figure 4.1. Even by eliminating the outliers from the analyses, it is seen that the relative variation in the critical flow rate of the pilot-scale grout slurry was greater than that of the laboratory grouts because of process fluctuations. The relative variation of the pilot-scale grouts, measured as a percentage (S.D./Mean*100), is less than $11 \%$. This compares with 3.4 and $1.1 \%$ for the laboratory grouts at 7 and $7.2 \mathrm{lb} / \mathrm{gal}$, respectively. The average critical flow rates of the laboratory grouts were about $30 \%$ less than those of the pilot-scale grouts because of

TABLE 4.1. Summary of Critical Flow Rate (gpm) Data for Pilot-Scale Grout Samples $(a)$ at Two Mix Ratios

\section{$7.0 \mathrm{lb} / \mathrm{gal}$}

\begin{tabular}{|c|c|c|c|c|c|c|c|c|c|}
\hline \multirow[b]{2}{*}{ Number } & \multicolumn{2}{|c|}{ GST } & \multicolumn{2}{|c|}{$\mathrm{NOZ}$} & \multirow{2}{*}{$\frac{L A B}{4}$} & \multicolumn{2}{|c|}{ GST } & \multirow{2}{*}{$\frac{\mathrm{NOZ}}{18}$} & \multirow{2}{*}{$\frac{L A B}{8}$} \\
\hline & 10 & (9) & 10 & (8) & & 18 & (17) & & \\
\hline Mean & 9.35 & $(8.73)$ & 11.39 & $(10.00)$ & 5.95 & 9.87 & $(9.25)$ & 10.24 & 6.23 \\
\hline Median & 8.75 & $(8.68)$ & 10.26 & $(9.80)$ & 5.89 & 9.26 & $(9.22)$ & 10.16 & 6.23 \\
\hline S.D. & 2.10 & $(0.80)$ & 3.21 & $(1.08)$ & 0.20 & 2.71 & $(0.64)$ & 0.57 & 0.07 \\
\hline$\%(b)$ & 22.5 & $(9.2)$ & 28.2 & $(10.8)$ & 3.4 & 27.5 & $(6.9)$ & 5.6 & 1.1 \\
\hline
\end{tabular}

(a) GST - Samples collected at the surge tank to the pump. NOZ - Samples collected at the discharge nozzle to the trench. $L A B$ - Samples produced and cured in the laboratory.

(b) Percent is calculated by: S.D./Mean times 100\%. 
differences in shear imparted during mixing and because of the longer dry blend storage time that reduces the effectiveness of the attapulgite. Each of these factors have been shown to affect the rheological properties of PSW grouts (Lokken et al. 1987). All grouts at these two mix ratios had critical flow rates that were less than the operating flow rate of $15 \mathrm{gpm}$, indicating that turbulent flow had been maintained throughout the test.

The slurry densities of the pilot-scale and laboratory grouts are compared in Table 4.2. Like the critical flow rates, the pilot-scale grout densities were more variable than their laboratory counterparts (even when not considering outliers). Again, process fluctuations, and possibly less controlled sampling and testing conditions, could be the main reason for the higher variability. The average slurry densities of the pilot-scale grouts were also less than the laboratory grouts because of the closed mixing system that impeded the release of entrained air.

\subsubsection{Drainable Liquids}

Grouts are formulated to be easily pumped and to maximize liquid waste loading. Because of these requirements, particle settling occurs, resulting in drainable liquids. The majority of the volume change caused by particle settling occurs within the first 24 hours after production. Thereafter, the

TABLE 4.2. Summary of Densities (1b/gal) for Pilot-Scale Grout Samples(a) at Two Mix Ratios

$7.0 \mathrm{lb} / \mathrm{gal}$

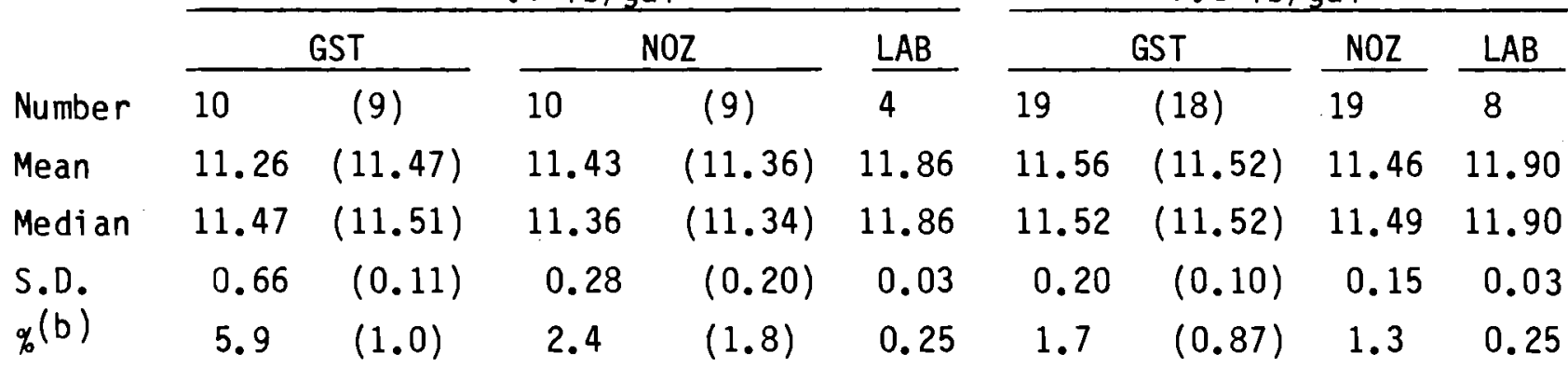

(a) GST - Samples collected at the surge tank to the pump. NOZ - Samples collected at the discharge nozzle to the trench. $L A B$ - Samples produced and cured in the laboratory.

(b) Percent is calculated by: S.D./Mean times $100 \%$. 
solids volume does not change appreciably, and some of the liquid readsorbs into the grout. A summary of the amount of drainable liquids present on the pilot-scale grouts is presented in Table 4.3. The average amount of liquids on the surge tank samples is slightly higher than on the samples collected at the nozzle. This is because of the thickening that occurred during pumping as discussed above. The laboratory-produced grouts had the greatest amount of drainable liquids. These grouts were produced about a month after the pilot-scale test. Previous studies (Lokken et al. 1987) have shown that the amount of shear imparted during mixing, as well as the amount of time dry blend containing attapulgite is stored have a significant impact on the rheological properties, i.e., longer storage times result in thinner grouts and more drainable liquids.

The drainable liquids from the pilot-scale grouts were highly variable as shown by the large standard deviation of the data. This variability is due to the variations in the viscosities, or critical flow rates between the samples. In contrast, the variation in the amount of drainable liquids on the laboratory grouts was considerably less because of the more exact mix ratio and controlled mixing conditions. TABLE 4.3. Summary of Drajpable Liquid Data (vol\%) for Pilot-Scale
Grout Samples

\begin{tabular}{|c|c|c|c|c|c|c|}
\hline & \multicolumn{3}{|c|}{$7.01 \mathrm{~b} / \mathrm{ga} 1$} & \multicolumn{3}{|c|}{$7.2 \mathrm{lb} / \mathrm{gal}$} \\
\hline & GST & $\mathrm{NOZ}$ & $\mathrm{LAB}$ & GST & $\mathrm{NOZ}$ & LAB \\
\hline Number & 8 & 9 & 4 & 13 & 13 & 8 \\
\hline Mean & 4.67 & 3.59 & 16.4 & 5.81 & 3.73 & 16.3 \\
\hline Median & 4.49 & 4.31 & 16.5 & 5.17 & 2.05 & 16.2 \\
\hline S.D. & 2.23 & 1.83 & 0.9 & 2.67 & 3.15 & 0.9 \\
\hline$q(b)$ & 48 & 51 & 5.5 & 46 & 85 & 5.5 \\
\hline
\end{tabular}

(a) GST = Grout collected at the surge tank to the pump. $\mathrm{NOZ}=$ Grout collected at the discharge nozzle to the trench.

$L A B=$ Grout produced in the laboratory.

(b) Percent is calculated by: S.D./Mean times 100\%. 
Although the average amount of drainable liquids on the grout samples collected at the discharge nozzle was greater than 3.5 vol\% after 28 days, the liquid that collected on the monolith was completely readsorbed within the first 30 days. It was estimated that approximately 7 vol\% was present on the monolith immediately after the test. These results indicate that the increased surface area of the monolith and the higher curing temperatures were beneficial for liquid readsorbtion.

\subsubsection{Penetration Resistance}

Setting, or hardening, rates of the pilot-scale grouts were determined by penetration resistance. According to ASTM C403-85, initial set is achieved when the penetration resistance reaches $500 \mathrm{psi}$, and final set occurs at 4000 psi. This procedure and its application are intended for conventional concrete and mortar uses, and are only applied to grouts as an indication of the relative setting rates. The development of penetration resistance of a typical sample is shown in Figure 4.2. Because of the high liquid loadings (compared with conventional concrete and mortar), and to the presence of setretarding chemicals in the PSW grouts, set times are relatively long; even after 28 days, the penetration resistance averaged only 3250 psi with a standard deviation of 570 psi for the surge tank and nozzle samples. By the ASTM definition, most of the samples failed to reach a final set (a penetration resistance of $4000 \mathrm{psi}$ ) within this time frame. Initial set (500 psi) was achieved between 2 and 3 days.

\subsection{CHARACTERIZATION OF SIMULATED PHOSPHATE/SULFATE WASTE AND BLEED LIQUID}

Samples of simulated PSW were collected during the pilot-scale test at the inlet to the mixer for the measurement of $\mathrm{pH}$ (corrosivity), EP toxicity, and chemical analysis. Samples of bleed liquid were collected from the trench on Mondays, Wednesdays, and Fridays for 28 days following the completion of the pilot-scale test. This section describes the results of these tests.

\subsection{1 pH (Corrosivity)}

Measurements of the $\mathrm{pH}$ of the PSW and bleed liquid were conducted to determine relative homogeneity of the simulated waste during the pilot-scale 


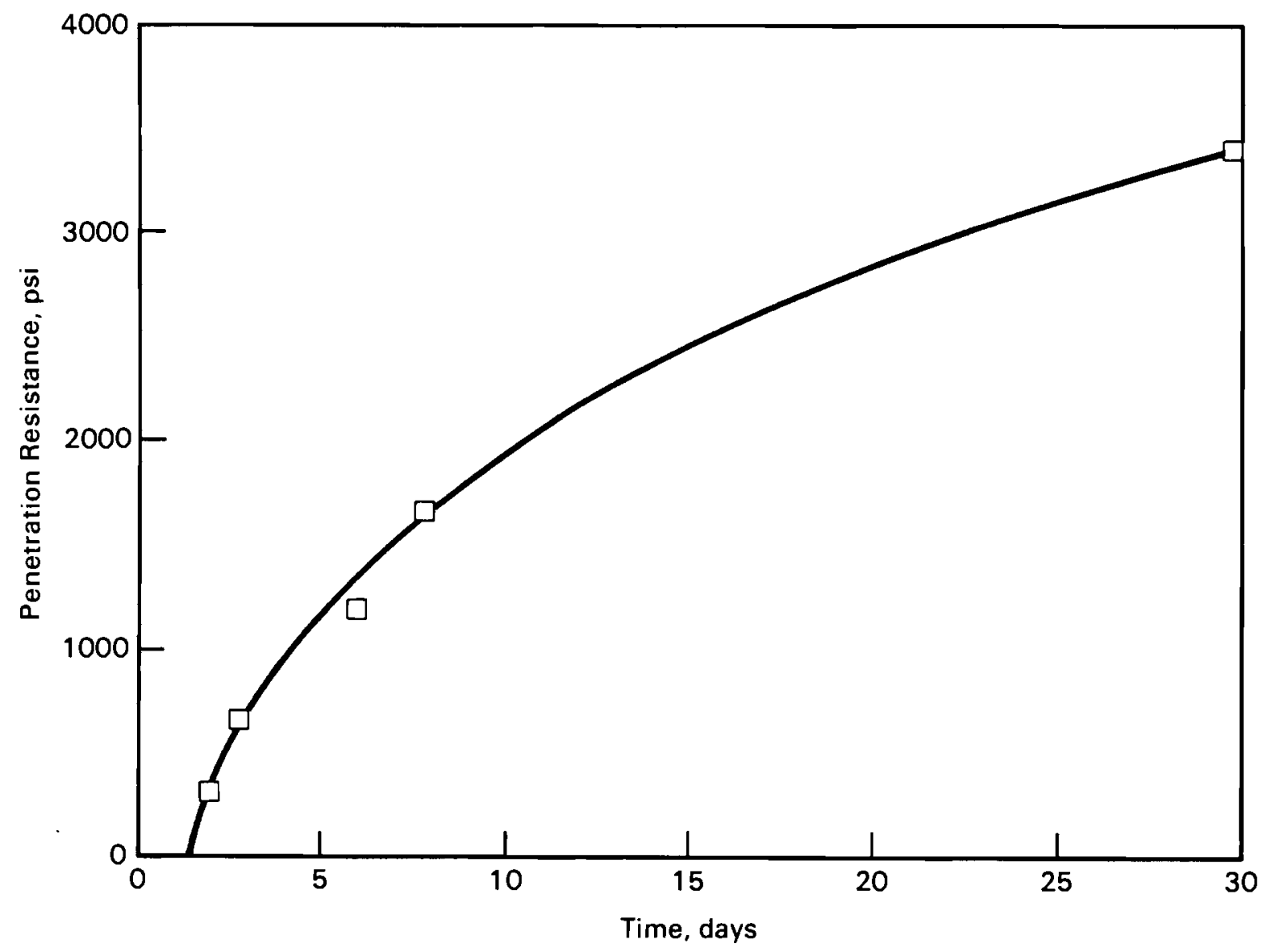

FIGURE 4.2. Development of Penetration Resistance of PSW Grout

test, and to determine whether the waste and/or the bleed liquid would be classified as corrosive wastes. The pH of 24 simulated PSW samples, measured immediately after sampling, averaged 12.20 with a standard deviation of $0.02 \mathrm{pH}$ units. At this value, the waste would not be considered corrosive. The small standard deviation in the $\mathrm{pH}$ measurements indicate that the waste was homogeneous, with respect to hydroxide content, throughout the test. The change in $\mathrm{pH}$ of the bleed liquid samples as a function of time after the test is shown in Figure 4.3. The pH steadily increased with time, starting at about 13.1 and ending at 13.25 after 28 days. The increase is caused by the continued hydration of the cementitious compounds in the grout and a subsequent increase in concentration of hydroxide in solution. At all time periods, the bleed liquid would be considered corrosive because the $\mathrm{pH}$ was greater than 12.5. 


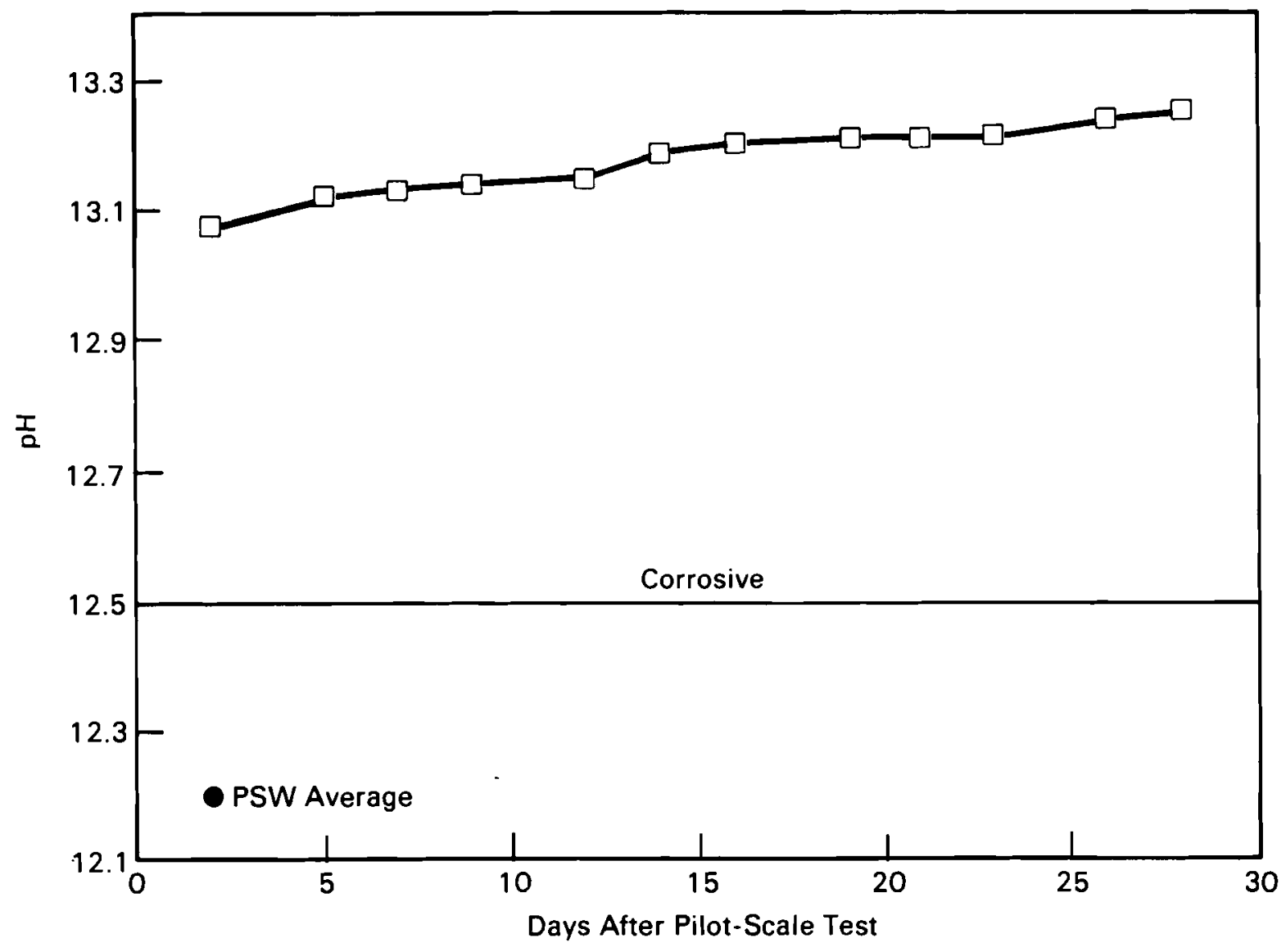

FIGURE 4.3. pH of Pilot-Scale Bleed Liquid

\subsubsection{Extraction Procedure Toxicity}

Samples of simulated PSW and bleed liquid were subjected to the EP Toxicity test for liquid wastes. In the procedure, the liquid samples are first filtered to determine the total solids content. If the value is less than $0.5 \mathrm{wt} \%$, the solids are discarded and the filtrate is used as the EP extract. The average filterable solids content in 12 PSW samples was 0.045 wt\% with a standard deviation of 0.005 . The small standard deviation in the filterable solids measurements indicates that the simulated waste solution was sufficiently agitated in the feed tank, resulting in a homogeneous feed to the pilot-scale grout process. The solids in the bleed liquid samples ranged from 0 to $0.05 \mathrm{wt} \%$. Since the solids content of both the waste and the bleed liquid samples was less than $0.5 \mathrm{wt} \%$, the filtrates were acidified and submitted for 
analysis. The results are summarized in Table 4.4. The "less-than" values listed in the table are the analytical detection limits for the particular method used. Based on these results, simulated PSW and bleed liquid do not exhibit the characteristic of EP Toxicity. The only two metals that were present in detectable quantities within the PSW and bleed liquid were arsenic and chromium. The arsenic was approximately the same in both liquids. The chromi um content, however, was considerably higher in the bleed liquid, presumably because of dissolution of fly ash.

\subsubsection{Chemical Analysis}

In addition to the analyses for the EP toxicity metals, additional analyses were conducted on the PSW and the bleed liquids. The results for PSW, summarized in Table 4.5, serve as another indication of the homogeneity of the waste solution chemistry. The concentration of the cations was found to be very constant, with the percent deviation from the mean approximating the precision of the analytical technique used.

Figure 4.4 shows the concentration of selected species in the bleed liquid as a function of time from completion of the test. In general, the

TABLE 4.4. Extraction Procedure Toxicity Results for Simulated PSW and Bleed Liquid

\begin{tabular}{|c|c|c|c|}
\hline Element & $\begin{array}{c}\text { Maximum } \\
\text { Concentration, } \\
\mathrm{mg} / \mathrm{L} \\
\end{array}$ & $\begin{array}{c}\text { PSW Extract } \\
\text { Concentration, } \\
\mathrm{mg} / \mathrm{L} \\
\end{array}$ & $\begin{array}{c}\text { Bleed Liquid } \\
\text { Concentration, } \\
\mathrm{mg} / \mathrm{L}\end{array}$ \\
\hline As & 5.0 & $1.1=1.5$ & $1.3-2.4$ \\
\hline $\mathrm{Ba}$ & 100.0 & $<0.02^{(a)}$ & $<0.02$ \\
\hline $\mathrm{Cd}$ & 1.0 & $<0.04$ & $<0.04$ \\
\hline $\mathrm{Cr}$ & 5.0 & $(0.2)^{(b)}$ & $3.4-3.7$ \\
\hline $\mathrm{Pb}$ & 5.0 & $<0.6$ & $<0.6$ \\
\hline $\mathrm{Hg}$ & 0.2 & $<0.05$ & $<0.05$ \\
\hline $\mathrm{Se}$ & 1.0 & $<0.5$ & $<0.5$ \\
\hline $\mathrm{Ag}$ & 5.0 & $<0.1$ & $<0.05$ \\
\hline
\end{tabular}

(a) Less-than values are the analytical detection limits.

(b) This value is near the detection limit. 
TABLE 4.5. Summary of Analytical Results for Simulated PSW

\begin{tabular}{|c|c|c|c|}
\hline Measurement & $\operatorname{Mean}(a)$ & $\begin{array}{c}\text { Standard } \\
\text { Deviation }\end{array}$ & Percent (c) \\
\hline Al $(\mathrm{mg} / \mathrm{L})$ & 8.94 & 0.33 & 3.7 \\
\hline $\mathrm{Na}(\mathrm{g} / \mathrm{L})$ & 11.39 & 0.31 & 2.7 \\
\hline$P(g / L)$ & 4.22 & 0.13 & 3.1 \\
\hline $\mathrm{Si} \quad(\mathrm{mg} / \mathrm{L})$ & 3.93 & 0.22 & 5.6 \\
\hline As $(m g / L)$ & 1.28 & 0.17 & 13.3 \\
\hline $\operatorname{TOC}^{(\mathrm{d})}(\mathrm{mg} / \mathrm{L})$ & 425 & 56.0 & 13.2 \\
\hline
\end{tabular}

(a) The mean was calculated from analysis of 12 samples.

(b) Standard deviation is one standard deviation (S.D.) from the mean.

(c) Percent is calculated by: S.D./Mean times $100 \%$.

(d) Total organic carbon.

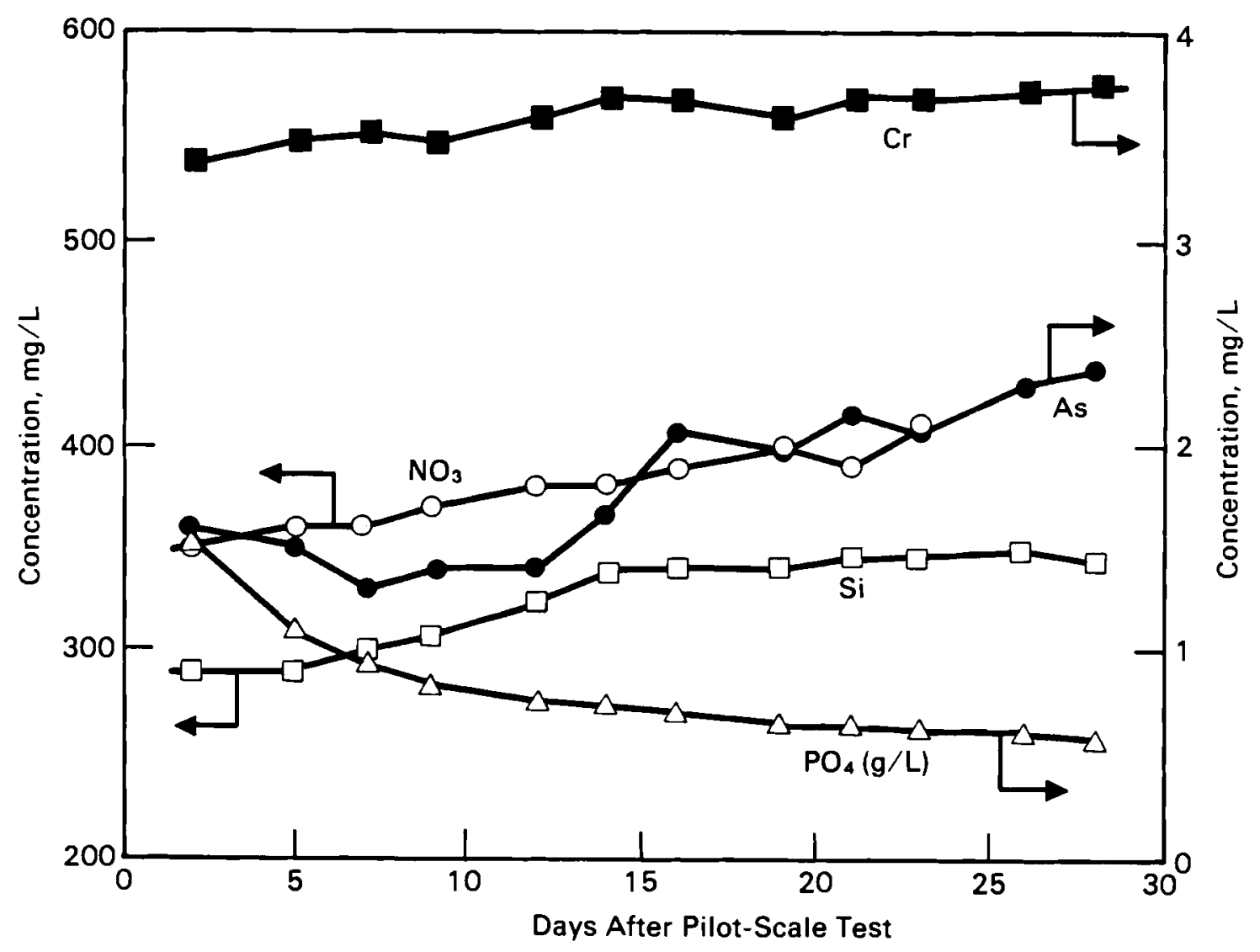

FIGURE 4.4. Changes in Bleed Liquid Concentration with Time 
concentration of most species increased with time. However, the rate of increase does not correspond to the rate that would be expected based on the decreasing volume of the bleed liquid with time. If water is lost from the bleed liquid solely because of hydration or evaporation, the nitrate concentration after 15 days would be twice the analyzed value (assuming unsaturated conditions). Because of these differences, it was concluded that the decrease in the volume of bleed liquid was due to physical adsorption of the liquid into the grout monolith because of increased capillarity resulting from microcracks and an increase in the capillary pores formed during hydration. The phosphate concentration decreased with time, most likely due to precipitation of calcium phosphate.

\subsection{CHARACTERIZATION OF DRY SOLIDS BLEND}

Samples of dry blend were collected from the storage bin of the dry solids feeder and characterized by $X$-ray diffraction and grain size.

\subsubsection{X-Ray Diffraction}

$X$-ray diffraction analys is of the dry blend samples was conducted to determine whether significant changes in the mineralogy, indicating segregation or compositional changes, occurred during the pilot-scale test. The dry blend consists primarily of Portland cement and fly ash. Portland cement is mostly crystalline, containing approximately $60 \%$ tricalcium silicate. Fly ash is, however, mostly amorphous with small amounts of quartz. The remaining two materials in the dry blend include an illitic clay and attapulgite clay, both of which contain quartz as an impurity.

The application of XRD methods to determine the amounts of individual crystalline phases in a multiphase mixture relies on accurate measurements of intensities of diffraction lines, the use of suitable standards, and consistent sample-mounting techniques. The accuracy in using this technique on dry blend samples is further complicated because nearly half of the blend is amorphous, which increases background noise and makes accurate determination of peak intensities difficult. 
In order to estimate the degree of consistency in the composition of the dry blend, integrated relative intensities of the major diffraction lines of tricalcium silicate, quartz, and clay were compared (Table 4.6). Based on the quartz/tricalcium silicate ratios, samples DB06 and DB22 appeared to be slightly enriched in quartz (i.e., less cement) compared with the other samples. However, within the limitations of XRD analysis, most of the dry blend samples appeared to be consistent in composition.

\subsubsection{Grain Size}

Grain size determinations were made on thirteen dry blend samples to determine relative homogeneity of the samples collected during the pilot-scale test. The residue remaining on a 200 -mesh sieve after wet sieving averaged

TABLE 4.6. Relative X-Ray Diffraction Intensities of Tricalcium Silicate, Quartz, and Clay Diagnostic Lines of Dry Blend Samples

\begin{tabular}{|c|c|c|c|c|}
\hline $\begin{array}{c}\text { Sample } \\
\text { No. } \\
\end{array}$ & $\begin{array}{r}\quad c 1 \text { ay } \\
\mathrm{d}=10.4(\mathrm{~b}) \\
\end{array}$ & $\begin{array}{l}\text { Quartz } \\
\mathrm{d}=3.34 \\
\end{array}$ & $\begin{array}{l}c 3 s^{(a)} \\
d=3.04 \\
\end{array}$ & $\begin{array}{c}C 3 S \\
d=2.78 \\
\end{array}$ \\
\hline DB01 & 6.5 & 79 & 55 & 100 \\
\hline $\mathrm{DBO2}$ & 8.3 & 78 & 78 & 100 \\
\hline DB04 & 4.3 & 82 & 62 & 100 \\
\hline DB06 & 5.8 & 70 & 51 & 78 \\
\hline DB08 & 5.9 & 80 & 60 & 100 \\
\hline DB10 & 6.7 & 86 & 58 & 99 \\
\hline DB 12 & 4.9 & 76 & 63 & 100 \\
\hline DB 14 & $-(c)$ & 74 & 59 & 100 \\
\hline DB 16 & 8.4 & 81 & 59 & 100 \\
\hline DB 19 & 4.1 & 71 & 52 & 100 \\
\hline DB 22 & 7.9 & 67 & 63 & 75 \\
\hline DB23 & 6.5 & 83 & 79 & 100 \\
\hline DB26 & 3.8 & 61 & 59 & 100 \\
\hline
\end{tabular}
(a) $d=$ d-spacing.
(b) C3S = Tricalcium Silicate.
(c) Not available. 
$4.0 \mathrm{wt} \%$ with a standard deviation of $0.3 \mathrm{wt} \%$. Based on these results, the grain size of the dry blend was determined to be consistent throughout the pilot-scale test.

\subsection{PROPERTIES OF CURED GROUT}

Several cured grout samples were tested and characterized for physical, mechanical, and chemical properties. The samples included grouts produced and cured in the laboratory, samples collected at the surge tank and trench discharge nozzle and cured under ambient conditions, samples obtained from the sampler tubes inserted into the monolith, and samples cored from the monolith. The sampler tube grouts were cured under monolith conditions for the first 28 days and then under ambient conditions until testing. One of the primary purposes of the pilot-scale test was to determine the homogeneity of grout within the large monolith. This section describes the results of testing and characterization and addresses the homogeneity.

\subsubsection{Density}

The geometric, bulk densities of cured pilot-scale grout samples are presented in Table 4.7. The measurements were conducted on samples that were prepared for compressive strength testing. The densities of the laboratory samples was about $4 \%$ higher than the surge tank and nozzle samples, primarily

TABLE 4.7. Density $\left(\mathrm{g} / \mathrm{cm}^{3}\right)$ Statistics for Pilot-Scale Grout Samples(a)

\begin{tabular}{|c|c|c|c|c|c|c|}
\hline Statistic & GST & $\mathrm{NOZ}$ & $L A B$ & ST1 & ST2 & Core \\
\hline $\begin{array}{l}\text { Number } \\
\text { Mean } \\
\text { Median } \\
\text { S, }(b) \\
\%(b)\end{array}$ & $\begin{array}{l}24 \\
1.482 \\
1.481 \\
0.015 \\
1.0\end{array}$ & $\begin{array}{l}24 \\
1.478 \\
1.482 \\
0.031 \\
2.1\end{array}$ & $\begin{array}{l}24 \\
1.541 \\
1.540 \\
0.008 \\
0.52\end{array}$ & $\begin{array}{l}20 \\
1.433 \\
1.435 \\
0.024 \\
1.7\end{array}$ & $\begin{array}{l}31 \\
1.421 \\
1.422 \\
0.021 \\
1.5\end{array}$ & $\begin{array}{l}16 \\
1.402 \\
1.401 \\
0.022 \\
1.6\end{array}$ \\
\hline
\end{tabular}

\footnotetext{
(a) GST - Samples collected at the surge tank.

NOZ - Samples collected at the discharge nozzle.

$L A B$ - Samples produced and cured in the laboratory.

ST1 - Samples from the grout sampler tubes; set 1.

ST2 - Samples from the grout sampler tubes; set 2. Core - Samples obtained from core drilling the monolith.

(b) Percent is calculated by: S.D./Mean times 100\%.
} 
because of the greater amount of particle settling that occurred in the laboratory samples (see Section 4.1). The samples from the monolith contained considerably more porosity, with average densities ranging from $1.4 \mathrm{~g} / \mathrm{cm}^{3}$ for the cores to $1.43 \mathrm{~g} / \mathrm{cm}^{3}$ for the sampler tube samples. These measurements represent an increase in porosity of about 5.4 vol\% over the samples that were cured in the laboratory.

The differences in porosity were caused by the procedures that were used in sample handling. The nozzle and surge tank samples were prepared by pouring freshly collected grout slurry into cylindrical molds. This procedure caused detrainment of any large air bubbles that would have been included as porosity. The differences in density of the sampler tube samples and the core samples were likely caused by the detrainment of air bubbles as the sampler tubes were inserted into the monolith.

\subsubsection{Compressive Strength}

Unconfined compressive strength measurements were conducted on the same samples that were discussed above. Table 4.8 summarizes the compressive strength data. The main purpose of conducting these tests was to determine homogeneity of grouts produced during the pilot-scale test, both as a function of production time and location within the monolith. As discussed above, the

TABLE 4.8. Compressive Strength (psi) Statistics for Pilot-Scale Grout Samples a

\begin{tabular}{|c|c|c|c|c|c|c|}
\hline Statistic & GST & NOZ & $L A B$ & ST 1 & ST2 & Core \\
\hline $\begin{array}{l}\text { Number } \\
\text { Mean } \\
\text { Median } \\
\text { S, } \text { (b) } \\
q_{0}(\mathrm{~s})\end{array}$ & $\begin{array}{r}24 \\
382 \\
375 \\
46 \\
12\end{array}$ & $\begin{array}{r}24 \\
440 \\
419 \\
95 \\
22\end{array}$ & $\begin{array}{r}24 \\
397 \\
395 \\
42 \\
11\end{array}$ & $\begin{array}{r}20 \\
258 \\
257 \\
51 \\
20\end{array}$ & $\begin{array}{r}31 \\
333 \\
344 \\
67 \\
20\end{array}$ & $\begin{array}{r}16 \\
402 \\
381 \\
52 \\
13\end{array}$ \\
\hline
\end{tabular}

(a) GST - Samples collected at the surge tank

NOZ - Samples collected at the discharge nozzle $L A B$ - Samples produced and cured in the laboratory

ST1 - Samples from the grout sampler tubes; set 1

ST2 - Samples from the grout sampler tubes; set 2

Core - Samples obtained from core drilling the monolith.

(b) Percent is calculated by: S.D./Mean times $100 \%$. 
properties of the pilot-scale grout slurry were more variable than the laboratory grouts because of slight variations in the mix ratio during processing. Consequently, the physical properties of the cured pilot-scale grouts were also expected to be more variable than those of the laboratory samples. This is evidenced by the values in the last row in the table.

Several comparisons can be made from the compressive strength data listed in the table. The first comparison is between the data from the samples collected at the surge tank and those collected at the trench discharge nozzle. These samples were collected at the same time periods during the pilot-scale test. The average strengths of the nozzle grouts were about $13 \%$ higher even though the densities were about the same. The only major difference between the two sets of samples was the increased shear imparted during pumping that may have resulted in more favorable microstructures.

The primary method of obtaining grout samples from the monolith was using the double-tube samplers described in Section 2.4. This method, while assuring sufficient samples for analysis, resulted in upset of the grout slurry during placement. The level of grout within the tubes was, in some cases, 12 to 24 inches higher than the corresponding monolith height. This may have acted to stratify the grout along the flow lines within the tube, or conversely, to homogenize the grout where stratifications had occurred during flow in the trench. Even though the densities of the cores were less than those of the sample-tube grouts, the compressive strengths of the cores were higher. The differences are believed to result from the upset of semi-rigid grout resulting in layers of lesser strength within the samples.

The sampling plan identified samples from 22 locations within the monolith for compressive strength testing to determine whether flow distance ( $x$ and $y$ directions) and/or depth ( $z$ direction) in the trench influenced grout properties. Figure 4.5 illustrates the apparent effect of flow distance on compressive strength. The data are plotted as a function of flow distance along the $x$ direction. Even though the regression line suggests a slight effect of flow distance, there was no statistically significant difference (at $95 \%$ confidence) in the strengths of grouts from one end of the trench to the other. The 


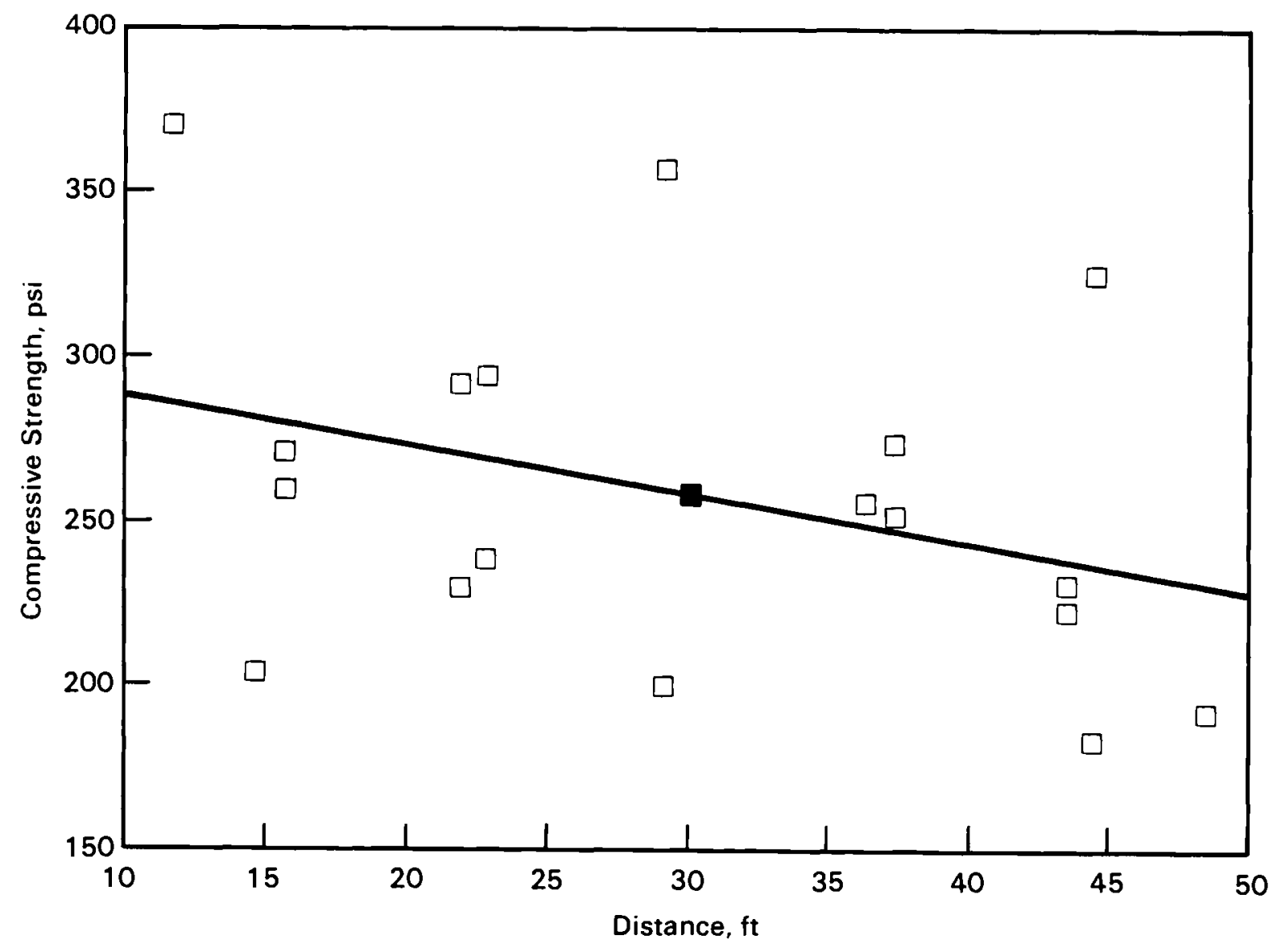

FIGURE 4.5. Compressive Strength of Pilot-Scale Monolith Samples as a Function of Flow Distance

correlation coefficients for compressive strength and flow along $(x)$ and across (y) the trench were -0.34 and -0.08 , respectively; the coefficient was -0.37 with depth $(z)$.

\subsubsection{Strength, Density, and Pulse Velocity Relationships}

Measurements of the ultrasonic pulse velocity through grout samples were conducted to determine whether this nondestructive technique could be used to predict physical properties, e.g., compressive strength. A summary of the 
ultrasonic pulse velocity is shown in Table 4.9. The ultrasonic pulse velocity, $v$, is related to the physical properties of materials by:

$$
v^{2}=(K) \frac{E}{D}
$$

where $K=a$ constant

$E=$ modulus of elasticity, and

$D=$ density.

It has been shown (Neville 1981) that the modulus of elasticity and compressive strength of concretes follow a straight-line relationship. If this relationship is valid for PSW grouts, then the compressive strengths, densities, and pulse velocities should have strong positive correlations. The correlation coefficients for various sets of data of PSW grouts is shown in Table 4.10. In general, the compressive strength and pulse velocity data correlated very well, with the highest correlation coefficient (0.93) for the nozzle samples. Separate correlations are given for the different sets of samples because of various curing times and conditions that can have an effect on the properties. The lowest correlations were seen between the compressive strength and density for the two sets of samples obtained from the sampler tubes. As discussed above, the densities of these samples were greater than those of the cored samples,

TABLE 4.9. Ultrasonic Pulse Velocity (m/s) Statistics for Pilot-Scale
Grout Samples

\begin{tabular}{|c|c|c|c|c|c|c|}
\hline Statistic & GST & $\mathrm{NOZ}$ & $L A B$ & ST1 & ST2 & Core \\
\hline Number & 24 & 24 & 24 & 20 & 31 & 16 \\
\hline Mean & 2180 & 2190 & 2240 & 1930 & 1990 & 2030 \\
\hline Median & 2180 & 2190 & 2240 & 1920 & 2000 & 2000 \\
\hline S, $p$ ) & 40 & 78 & 16 & 60 & 75 & 131 \\
\hline & 1.8 & 3.6 & 0.71 & 3.1 & 3.8 & 6.5 \\
\hline
\end{tabular}

\footnotetext{
(a) GST - Samples collected at the surge tank NOZ - Samples collected at the discharge nozzle LAB - Samples produced and cured in the laboratory

ST1 - Samples from the grout sampler tubes; set 1

ST2 - Samples from the grout sampler tubes; set 2

Core - Samples obtained from core drilling the monolith.

(b) Percent is calculated by: S.D./Mean times 100\%.
} 
TABLE 4.10. Correlation Coefficients for Compressive Strength,

\begin{tabular}{|c|c|c|c|c|c|c|}
\hline Correlation (b) & GST & $\mathrm{NOZ}$ & LAB & ST1 & ST2 & Core \\
\hline $\begin{array}{l}\text { CS/PV } \\
\text { CS/DEN }\end{array}$ & $\begin{array}{l}0.75 \\
0.81\end{array}$ & $\begin{array}{l}0.93 \\
0.87\end{array}$ & $\begin{array}{l}0.60 \\
0.46\end{array}$ & $\begin{array}{l}0.66 \\
0.42\end{array}$ & $\begin{array}{l}0.78 \\
0.23\end{array}$ & $\begin{array}{l}0.73 \\
0.68\end{array}$ \\
\hline PV/DEN & 0.76 & 0.95 & 0.84 & 0.73 & 0.49 & 0.67 \\
\hline
\end{tabular}

(a) GST - Samples collected at the surge tank

NOZ - Samples collected at the discharge nozzle

LAB - Samples produced and cured in the laboratory

ST1 - Samples from the grout sampler tubes; set 1

ST2 - Samples from the grout sampler tubes; set 2

Core - Samples obtained from core drilling the monolith

(b) $C S / P V=$ Compressive strength versus pulse velocity

CS/DEN = Compressive strength versus density

$\mathrm{PV} / \mathrm{DEN}=$ Pulse Velocity versus density

presumably because of the upset of the grout and compression or release of air bubbles as the tubes were inserted into the grouts. The upset also resulted in lower compressive strengths because of the disruption of the partially set grout.

\subsubsection{Corrosivity}

The corrosivity potential of the pilot-scale grout was determined by the WDOE 83-13 method. In this procedure, a solid material is mixed with an equal weight of distilled deionized water, and the $\mathrm{pH}$ of the resulting solution is measured. An average $\mathrm{pH}$ for each grout sample was calculated using the logarithmic average of $\mathrm{pH}$ 's obtained from three trials for each of 22 samples from the monolith. The pH ranged from 11.7 to 11.8 .

\subsubsection{Leach Tests}

The American Nuclear Society (ANS) 16.1 leach test was conducted on 22 samples of grout obtained from the sampler tubes. The grout had cured 23 to 24 weeks prior to the start of the leach tests. The tests continued through 90 days. Although this test is intended for use on radioactive low-level waste forms, it was applied here to determine the relative leaching resistance of major cations and to determine homogeneity of the grout within the monolith. The ANS 16.1 leach test is designed to determine a "figure of merit" parameter 
called the leachability index $(L)$. The leachability index for a given species is defined as the negative logarithm (base 10) of the effective diffusion coefficient (D) of that species. The effective diffusivity is given by:

$$
D=\pi\left[\frac{a_{n} / A_{0}}{(\Delta t)_{n}}\right]^{2}\left[\frac{v}{s}\right]^{2} T
$$

where $D=$ effective diffusivity, $\mathrm{cm}^{2} / \mathrm{s}$,

$$
\begin{aligned}
\text { an }= & \text { concentration of ion released from the specimen during the } \\
& \text { leaching interval } n, \\
A_{0}= & \text { total amount of species in the specimen at the beginning of the } \\
& \text { leach test } \\
(\Delta t) n= & t n-t n-1 \text {, duration of the n-th leaching interval, } s \\
V= & \text { volume of specimen, } \mathrm{cm}^{3} \\
\mathrm{~S}= & \text { geometric surface area of specimen, } \mathrm{cm}^{2} \\
\mathrm{~T}= & {\left[1 / 2\left(\mathrm{tn}^{1 / 2}+\mathrm{tn}-1^{1 / 2}\right)\right]^{2} \text {, representing the "mean time" of the } } \\
& \text { leaching interval, } \mathrm{s} .
\end{aligned}
$$

The treatment of the data from this type of leach test assumes that the release of ions from the waste form is controlled by diffusion. For pure diffusional release, the cumulative amount of species released from the sample plotted as a function of the square root of time would yield a straight line passing through the origin at time zero. This type of plot is shown in Figure 4.6 for the average cumulative fraction sodium released from the 22 pilotscale grout samples. The slope of the release curve decreases between leach intervals, representing a decrease in diffusion coefficients with time. The average leach indices for the various time periods ranged from 7.7 during the 


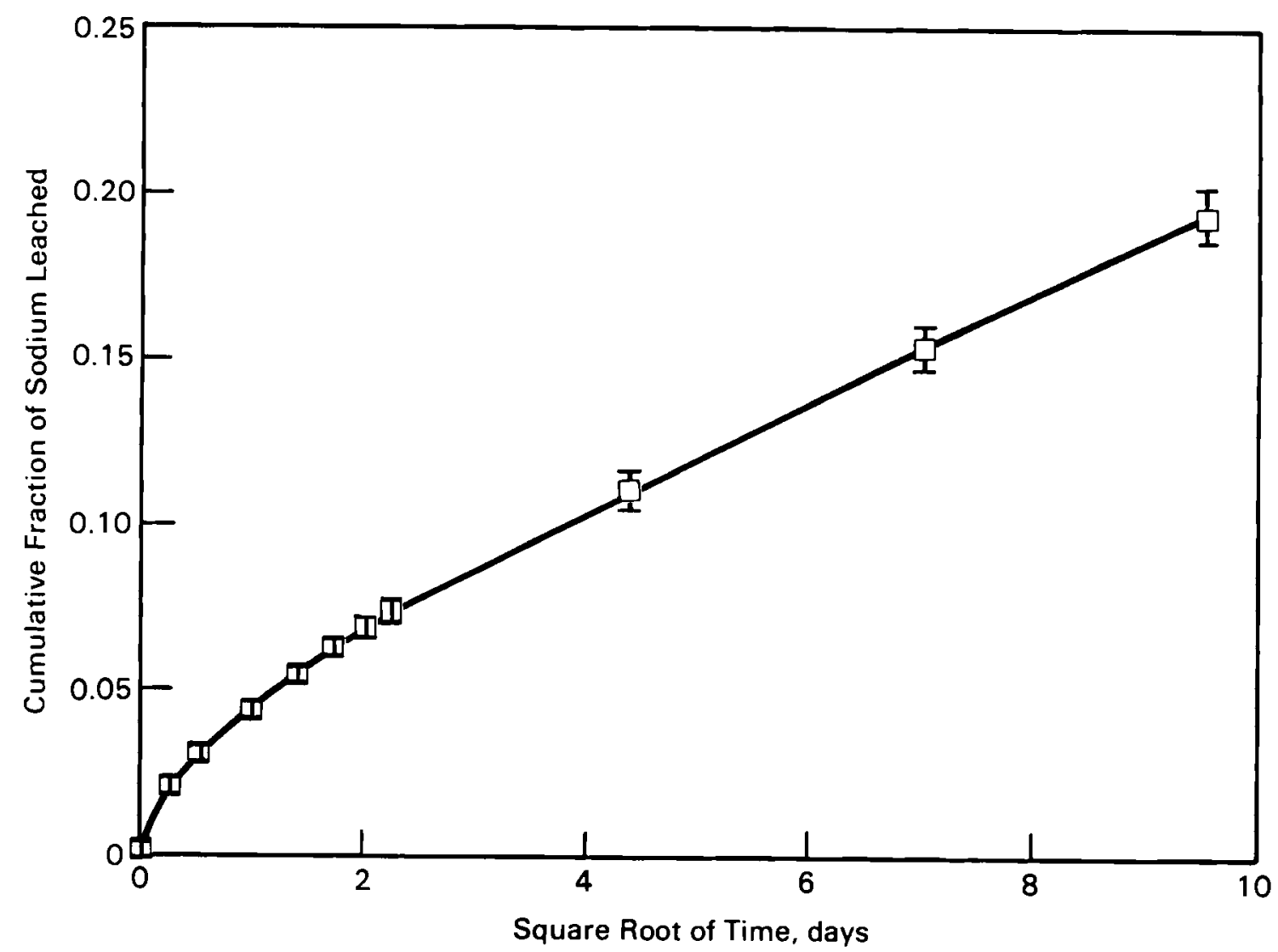

FIGURE 4.6. Cumulative Fraction Sodium Leached from Pilot-Scale Grout

initial stage of the test to 9.1 after 90 days. According to the ANS 16.1 procedure, reporting of the leach index must also include a relative "bias" term when:

$$
\frac{\left(L_{7}+L_{8}+L_{9}+L_{10}\right)-\left(L_{1}+L_{2}+L_{3}+L_{4}\right)}{\left(L_{1}+L_{2}+L_{3}+L_{4}\right)}> \pm 5 \%
$$

The average sodium leach index for the pilot-scale samples was $8.7+7 \%$, indicating that the leach index was greater (i.e., the grouts exhibited better leach resistance) at the latter stages of the leach test.

Further analysis of the leach data indicates that the relative leach resistance of the grout samples from different parts of the trench was very consistent, illustrated by the error bars in the figure. The standard 
deviations were less than about $10 \%$ of the mean values, which is typically within the precision of the analytical methods. Therefore, it appears that no significant differences in leach behavior existed between samples from the various places in the pilot-scale trench.

\subsubsection{Toxicity Characteristic Leaching Procedure (TCLP)}

The results of testing 22 grout samples from the monolith using the TCLP are presented in Table 4.11. Most of the regulated elements were not present in solution above the analytical detection limits. Barium and chromium were the only metals detectable. Their levels were about 200 times less than the regulatory threshold values where the PSW grout would be considered hazardous.

\subsubsection{Microstructural Characterization}

Several samples of pilot-scale grout and laboratory-produced grout were examined using scanning electron microscopy. Figure 4.7 shows fracture surfaces of grout samples produced and cured in the laboratory. The top micrograph represents a sample from the top $1 / 2$ in. of a 9-in. long cylinder; the bottom is from the bottom $1 / 2 \mathrm{in}$. The top of the sample was characterized by a much more open structure with distinct individual particles. More visible voids were also present in this sample. The surface of the bottom sample was considerably more dense and contained massive hydration products. Although the

TABLE 4.11. TCLP Results for Pilot-Scale Grout

\begin{tabular}{|c|c|c|}
\hline Element & $\begin{array}{c}\text { Analyzed } \\
\text { Average, } \mathrm{mg} / \mathrm{L}(\mathrm{a})\end{array}$ & $\begin{array}{l}\text { Regulatory } \\
\text { Limit, mg/L }\end{array}$ \\
\hline As & $<0.5^{(b)}$ & 5.0 \\
\hline $\mathrm{Ba}$ & 0.47 & 100.0 \\
\hline $\mathrm{Cd}$ & $<0.008$ & 1.0 \\
\hline $\mathrm{Cr}$ & 0.04 & 5.0 \\
\hline $\mathrm{Pb}$ & $<0.12$ & 5.0 \\
\hline $\mathrm{Hg}$ & $<0.002$ & 0.2 \\
\hline $\mathrm{Se}$ & $<0.05$ & 1.0 \\
\hline $\mathrm{Ag}$ & $<0.5$ & 5.0 \\
\hline
\end{tabular}

(a) Average of 22 samples.

(b) "Less than" values are analytical detection limits. 

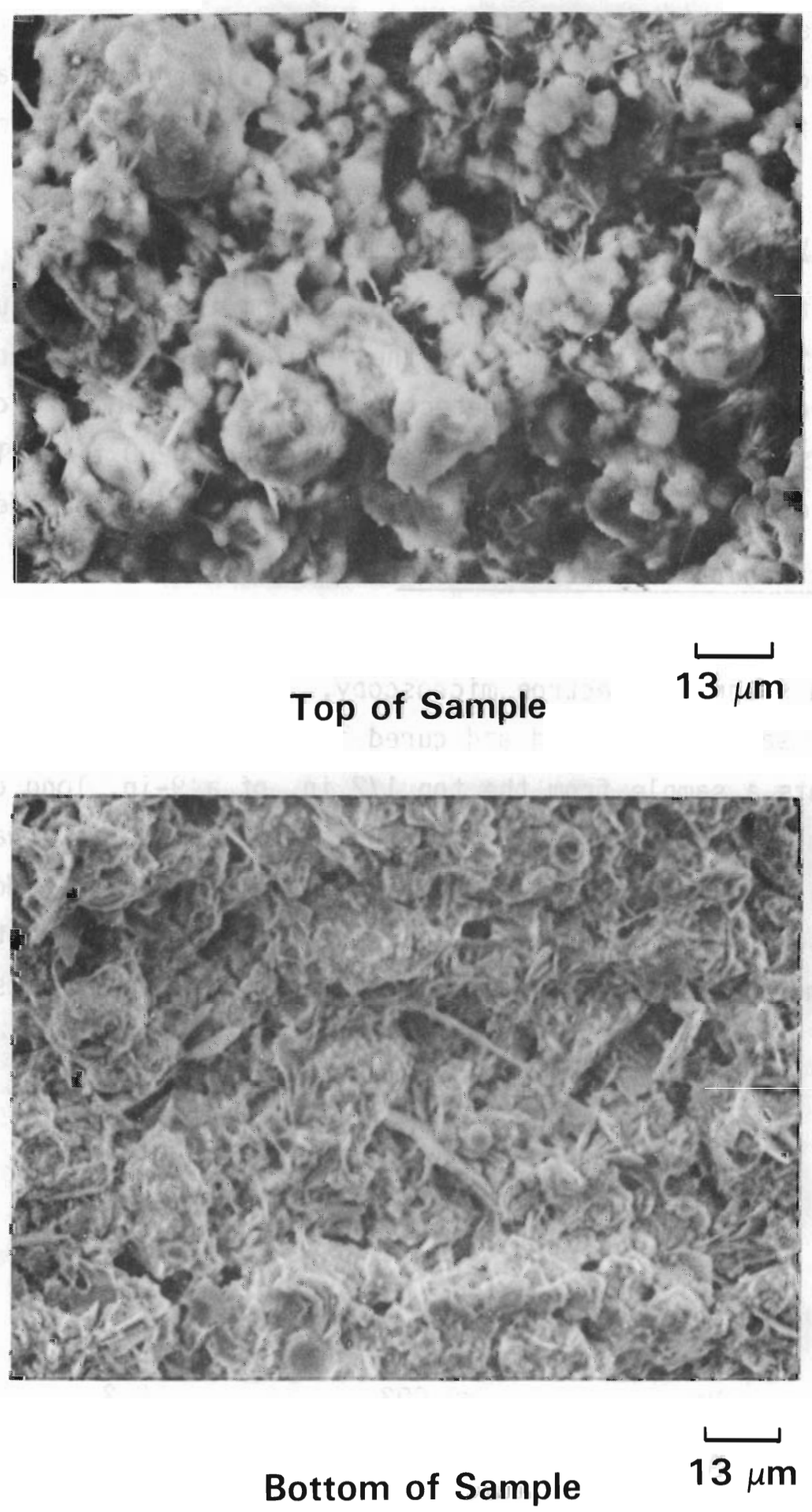

FIGURE 4.7. Scanning Electron Micrographs of Fracture Surfaces of Laboratory-Produced PSW Grouts 
morphology of the individual particles could still be seen, the particles were contained within the dense hydration products. Several smaller voids were also present.

Figure 4.8 shows micrographs of fracture surfaces of pilot-scale grout samples. The top micrograph is from a sample about $6 \mathrm{in}$. below the monolith surface; the bottom is from a sample about $3 \mathrm{ft}$ below the surface. Several differences were evident among these samples; however, the differences were not as dramatic as those in the laboratory samples. The hydration products appeared more dense in the bottom sample. Individual particles were more evident in the top sample, possibly indicating a lesser degree of hydration. The top sample was subjected to conditions closer to ambient than the bottom sample.

Comparing microstructures of the bottom sample of the laboratory grout with that of the pilot-scale samples reveals less noticeable voids and a finer microstructure in the lab grout. Fewer voids in the lab grout were expected due to its higher density. The finer microstructure may have resulted from the differences in processing and/or the differences in curing conditions (the pilot-scale grout reached temperatures of up to $65^{\circ} \mathrm{C}$ ). 

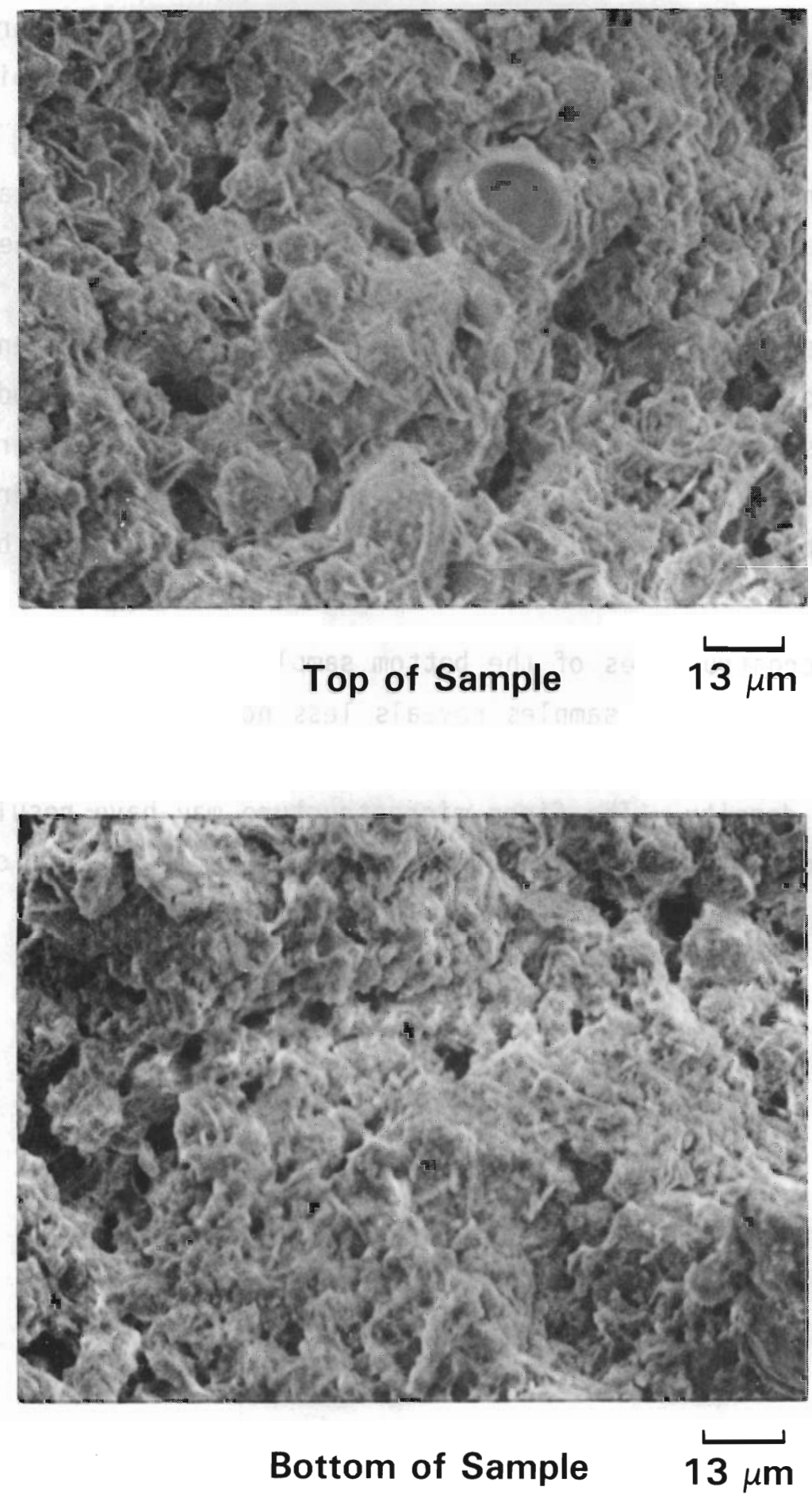

FIGURE 4.8. Scanning Electron Micrographs of Fracture Surfaces of Pilot-Scale Grouts 


\subsection{CONCLUSIONS}

Based on the results presented in this report, the following conclusions can be made:

- Minor process upsets resulted in varying rheological properties of grout slurries.

- Pumping of grout slurry through $150 \mathrm{ft}$ of 1-in. pipe increased viscosity and resulted in less drainable liquids compared with grout slurry that had not been pumped.

- Critical flow rates of laboratory-produced grout slurries were less than the pilot-scale grout slurries because of differences in shear during mixing and because of dry blend storage time.

- Bleed liquid in the pilot-scale trench would be considered corrosive because of $\mathrm{pH}$ values greater than 12.5 .

- Grout from the pilot-scale test would be considered noncorrosive because of $\mathrm{pH}$ values of less than 12.5 .

- Both the simulated PSW and the bleed liquid passed the EP toxicity test, although the $\mathrm{Cr}$ content of the bleed liquid extract was $80 \%$ of the allowable limit.

- Simulated PSW was uniform throughout the test, based on $\mathrm{pH}$, solids content, and chemical composition.

- The grain size of the dry blend was consistent throughout the test.

- Location within the monolith did not have an influence on the compressive strength of the grouts.

- Compressive strengths of the cored grout samples were slightly higher than those of grouts from the sampler tubes.

- Leach behavior of the grout monolith samples was uniform throughout the trench. Relative variation between samples was less than $10 \%$.

- The leachability index for sodium averaged 8.7 . 


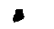

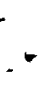

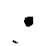

.

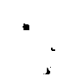




\subsection{REFERENCES}

American Nuclear Society (ANS). 1984. Measurement of the Leachability of Solidified Low-Level Radioactive Waste. ANS 16.1, American Nuclear Society, Champaign, Il1inois.

American Society for Testing and Materials (ASTM). 1983. 1983 Annual Book of ASTM Standards. Vol. 4.01, Cement; Lime; Gypsum, American Society for Testing and Materials, Philadelphia, Pennsylvania.

American Society for Testing and Materials (ASTM). 1985. 1985 Annual Book of ASTM Standards. Vol. 4.02, Concrete and Mineral Aggregates, American Society for Testing and Materials, Philadelphia, Pennsylvania.

Fow, C. L., D. H. Mitchell, R. L. Treat, and C. R. Hymas. 1987. Pilot-Scale Grout Production Test with a Simulated Low-Level Waste. PNL-6148. Pacific Northwest Laboratory, Richland, Washington.

Lokken, R. 0., P. F. C. Martin, W. M. Bowen, H. Harty, and R. L. Treat. 1987. Variability in Properties of Grouted Phosphate/Sulfate N-Reactor Waste. PNL-6030, Pacific Northwest Laboratory, Richland, Washington.

Neville, A. M. 1981. Properties of Concrete. Third Addition. Pitman Publishing Inc., Marshfield, Massachusetts.

Smith, D. K. 1976. Cementing. Monograph Volume 4 of Henry L. Doherty Series, Henry L. Doherty Memorial Fund of AIME and Society of Petroleum Engineers of AIME, New York.

State of Washington Department of Ecology (WDOE). 1984. "Chemical Testing Methods for Complying with the Dangerous Waste Regulation," Chapter 173-303, Washington Administration Code, State of Washington, 0lympia, Washington.

U.S. Environmental Protection Agency (U.S. EPA). 1982. "Test Methods for the Evaluation of Solid Waste." Physical/Chemical Properties. SW-846. GP0 Stock No. 055-002-8100-2. Washington, D.C.

U.S. Environmental Protection Agency (U.S. EPA). 1986. "Appendix I to Part 268 -- Toxicity Characteristic Leaching Procedure (TCLP)." Federal Register, Vol. 51, No. 216, November 7, 1986, U.S. Environmental Protection Agency, Washington, D.C. 


\section{DISTRIBUTION}

No. of

Copies

OFFSITE

10 DOE Office of Scientific and Technical Information

3 DOE Office of Defense Waste \& Transportation Management GTN

Washington, DC 20545

ATTN: T. C. Chee, DP -123

G. H. Daly, DP-124

J. H. Lytle, DP-12

6 DOE Office of Remedial Action GTN and Waste Technology

Washington, DC 20545

ATTN: J. A. Coleman, NE-25

T. W. McIntosh, NE-25

H. Stelling, NE-25

W. R. Voight, NE-20

H. F. Walter, NE-25

J. B. Zorn, NE-25

A. T. Clark

Division of Fuel Material Safety

Nuclear Regulatory Commission Washington, DC 20555

V. Stello

Office of the Executive

Director for Operations

Mail Station 6209

Nuclear Regulatory Commission

Washington, DC 20555

G. L. Sjoblom

Environmental Protection Agency

Office of Radiation Programs

401 M Street, S.W.

Washington, DC 20460
No. of

Copies

J. M. McGough

DOE Albuquerque Operations Office

P. 0. Box 5400

Albuquerque, NM 87185

P. G. Hagen

Joint Integration Office

Bldg. 3, 2nd Floor

2201 San Pedro N.E.

Albuquerque, NM 87110

E. Maestas

DOE West Valley Operations Office

P. 0. Box 191

West Valley, NY 14171

2 DOE Idaho Operations Office

550 Second Street

Idaho Falls, ID 83401

ATTN: J. P. Hamric

S. T. Hinschberger

F. T. Fong

DOE San Francisco Operations

1333 Broadway

Oakl and, CA 94612

M. R. Jugan

DOE Oak Ridge Operations Office

P. O. Box E

Oak Ridge, TN 37830

W. J. Brumley

DOE Savannah River Operations Office

P. 0. Box A

Aiken, SC 29801

M. J. Steindler

Argonne National Laboratory

9700 South Cass Avenue

Argonne, IL 60439 
No. of

Copies

C. S. Abrams

Argonne National Laboratory

P.0. Box 2528

Idaho Falls, ID 83401

3 Battelle Memorial Institute Project Management Division $505 \mathrm{King}$ Avenue

Columbus, $\mathrm{OH} 43201$

ATTN: W. A. Carbeiner

W. S. Madia

B. Rawles

L. D. Ramspott

Lawrence Livermore National Laboratory

University of California

P.0. Box 808

Livermore, CA 94550

D. T. Oakley, MS 671

Los Alamos Scientific Laboratory

P.0. Box 1663

Los Alamos, NM 87544

3 Oak Ridge National Laboratory

P.0. Box $Y$

Oak. Ridge, TN 37830

ATTN: E. W. McDaniel

T. L. Sams

O. K. Tallent

4 Sandia Laboratories

P.0. Box 5800

Albuquerque, NM 87185

ATTN: D. R. Anderson

R. W. Lynch

W. Weart

Technical Library

J. R. Berreth

Westinghouse Idaho Nuclear Co., Inc.

P.0. Box 4000

Idaho Fa11s, ID 83401
No. of

Copies

4 E. I. du Pont de Nemours \& Company, Inc.

Savannah River Laboratory

Aiken, SC 29801

ATTN: R. L. Hooker

C. A. Langton

H. F. Sturm, Jr.

E. Wilhite

E. A. Jennrich

EG\&G Idaho

P.0. Box 1625

Idaho Falls, ID 83415

R. Shaw

Electric Power Research

Institute

3412 Hillview Avenue

P.0. Box 10412

Palo Alto, CA 94303

2 West Valley Nuclear Services

Company

West Valley, NY 14171

ATTN: C. C. Chapman

J. M. Pope

J. L. White

Energy Research \& Development Authority

Empire State Plaza

Albany, NY 12223

ONSITE

9 DOE Richland Operations Office

E. M. Bowers

E. A. Bracken

C. E. Collantes

C. R. DeLannoy

R. E. Gerton

R. D. Izatt

N. T. Karagianes

M. W. Shupe

J. D. White 
No. of

Copies

31 Westinghouse Hanford Company

J. M. Allison (10)

T. B. Bergman

No. of

Copies

D. E. Bowers

L. C. Brown

M. L. Carrigan

T. E. Dabrowski/W. J. Kyriazis

C. DeFigh-Price

B. H. Gilbert

J. D. Herb

R. A. Kaldor

R. E. Lerch

W. G. Richmond

J. G. Riddelle

A. R. Tedeschi

J. E. VanBeek

L. D. Vanselow

J. D. Watrous

G. F. Williamson

D. D. Wodrich

R. D. Wojtasek

D. E. Wood

L. L. Zahn

56 Pacific Northwest Laboratory

W. W. Ballard, Jr.

W. F. Bonner

K. A. Borgeson

L. R. Bunne 11

T. T. Claudson

D. G. Coles

W. T. Farris

C. L. Fow

Pacific Northwest Laboratory (contd)

S. E. Geldart

K. A. Hawley

D. G. Huizenga

C. R. Hymas

R. S. Kemper

D. A. Lamar

G. V. Last

R. 0. Lokken (10)

P. F. C. Martin

J. L. McEl roy

T. J. McLaughl in

G. B. Mellinger

D. H. Mitche11 (5)

B. A. Napier

M. A. Reimus

R. G. Schreckhise

R. J. Serne

G. H. Sewart

J. W. Shade

D. R. Sherwood

T. L. Stewart

J. L. Straalsund

D. M. Strachan

G. P. Streile

V. W. Thomas

L. E. Thompson

R. L. Treat

P. J. Turner

Publishing Coordination (2)

Technical Information (5) 


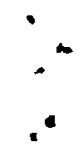

.

$\because$

$=$

.

$\because$

,

$+$

$-1$ $-$ 